\title{
Assessing ecosystem impacts on health: A tool review
}

Citation for published version (APA):

Oosterbroek, B., de Kraker, J., Huynen, M. M. T. E., \& Martens, P. (2016). Assessing ecosystem impacts on health: A tool review. Ecosystem Services, 17, 237-254. https://doi.org/10.1016/j.ecoser.2015.12.008

Document status and date:

Published: 01/02/2016

DOI:

10.1016/j.ecoser.2015.12.008

Document Version:

Publisher's PDF, also known as Version of record

Document license:

Taverne

Please check the document version of this publication:

- A submitted manuscript is the version of the article upon submission and before peer-review. There can be important differences between the submitted version and the official published version of record.

People interested in the research are advised to contact the author for the final version of the publication, or visit the DOI to the publisher's website.

- The final author version and the galley proof are versions of the publication after peer review.

- The final published version features the final layout of the paper including the volume, issue and page numbers.

Link to publication

\footnotetext{
General rights rights.

- You may freely distribute the URL identifying the publication in the public portal. please follow below link for the End User Agreement:

www.umlib.nl/taverne-license

Take down policy

If you believe that this document breaches copyright please contact us at:

repository@maastrichtuniversity.nl

providing details and we will investigate your claim.
}

Copyright and moral rights for the publications made accessible in the public portal are retained by the authors and/or other copyright owners and it is a condition of accessing publications that users recognise and abide by the legal requirements associated with these

- Users may download and print one copy of any publication from the public portal for the purpose of private study or research.

- You may not further distribute the material or use it for any profit-making activity or commercial gain

If the publication is distributed under the terms of Article $25 \mathrm{fa}$ of the Dutch Copyright Act, indicated by the "Taverne" license above, 


\title{
Assessing ecosystem impacts on health: A tool review
}

\author{
Bram Oosterbroek $^{a, *}$, Joop de Kraker ${ }^{a, b}$, Maud M.T.E. Huynen ${ }^{a}$, Pim Martens ${ }^{a}$ \\ a International Centre for Integrated Assessment and Sustainable Development, Maastricht University, PO Box 616, 6200 MD Maastricht, The Netherlands \\ ${ }^{\mathrm{b}}$ Faculty of Management, Science \& Technology, Open Universiteit, 6401 DL Heerlen, The Netherlands
}

\section{A R T I C L E I N F O}

\section{Article history:}

Received 9 October 2015

Received in revised form 23 December 2015

Accepted 24 December 2015

Available online 30 January 2016

Keywords:

Ecosystem services

Human health

Computer-based tools

Ecosystem disservices

Ecosystem assessment

\begin{abstract}
A B S T R A C T
In the past decade, interest in the impacts of ecosystem change on human health has strongly increased. The ecosystem-health relationship, however, is characterized by several complexity aspects, such as multiple and diverse health impacts - both positive and negative - and a strong interaction with socioeconomic factors. As these aspects strongly determine the outcomes of the ecosystem-human health relationship, they should be accounted for in assessments. We identified 14 ecosystem services and six ecosystem disservices with a direct impact on human health. An extensive search and selection procedure yielded eleven computer-based tools that we evaluated regarding their suitability for assessment of the ecosystem-health relationship. Nine of 14 health-related ecosystem services are addressed by one or more of these tools. However, most tools do not include the final step of actually assessing the associated health outcomes such as mortality or disease incidence. Furthermore, the review shows that each complexity aspect is addressed by several of the evaluated tools, but always in an incomplete way. We recommend that further tool development should focus on improved integration of socio-economic factors and inclusion of ecosystem disservices. This would allow better assessment of the net contribution of ecosystems to human health.
\end{abstract}

(c) 2015 Elsevier B.V. All rights reserved.

\section{Introduction}

Following the Millennium Ecosystem Assessment (MA, 2005d), the past decade has seen a growing interest in the impacts of ecosystem change on human health. The MA aimed to assess the consequences of ecosystem change for human well-being, with health as one of its main components. This is especially apparent through MA chapters with a dominant focus on health (such as Corvalan et al., 2005; Levy et al., 2005; MA, 2005c; Patz and Confalonieri, 2005). The MA concluded that, of all the examined services ecosystems provide, approximately $60 \%$ were being degraded or used unsustainably, including services that relate to human health such as air and water purification and the regulation of natural hazards. Furthermore, the MA pointed out that the health-related Millennium Development Goals on hunger, child mortality and disease are particularly dependent on sound ecosystem management, and that public health costs associated with damage to ecosystem services can be substantial (MA, 2005d).

Hence, the MA has contributed significantly to the emerging awareness that, expressed in public health terms, ecosystem conditions should be understood as important determinants of

\footnotetext{
* Corresponding author.

E-mail addresses: bram.oosterbroek@maastrichtuniversity.nl (B. Oosterbroek), j.dekraker@maastrichtuniversity.nl (J. de Kraker),

m.huynen@maastrichtuniversity.nl (M.M.T.E. Huynen),

p.martens@maastrichtuniversity.nl (P. Martens).
}

human health, operating at a higher hierarchical level of causality and shaping the context in which more direct health determinants operate and develop (Huynen et al., 2005). One of the three overall main problems highlighted by the MA experts was the established but incomplete evidence that changes being made in ecosystems have important consequences for human well-being and health (MA, 2005d). More recent work highlights the same issue, more specifically for health: the report of The Rockefeller FoundationLancet Commission on planetary health states as key message that within the concept of planetary health, human health depends on natural systems, which are being degraded to an unprecedented extent (Whitmee et al., 2015). Furthermore, the World Health Organization's review on biodiversity and human health summarize that the continued decline of biodiversity (being a key environmental determinant of human health) is reducing lifesustaining ecosystem services, often leading to negative outcomes for health (WHO and CBD Secretariat, 2015). Consequently, there is a need for research and policies to start accounting for ecosystem impacts on health as well as for the associated drivers of ecosystem change, such as climate change and land use change.

A growing number of health researchers calls for such broader approaches towards health, using various terminologies such as 'ecological perspective on health' (McLaren and Hawe, 2005),'social-ecological systems perspective on health' (McMichael, 1999), 'ecosystem approach to public health' (Arya et al., 2009), 'ecological public health' (Morris, 2010; Rayner and Lang, 2012) and 'eco-epidemiology' (Soskolne and Broemling, 2002; Susser and Susser, 1996). The importance 
Ecosystem: "a dynamic complex of plant, animal, and microorganism communities and the nonliving environment, interacting as a functional unit. (...) A well-defined ecosystem has strong interactions among its components and weak interactions across its boundaries" (MA, 2005d)

Ecosystem services (ES): "the benefits people obtain from ecosystems" (MA, 2005d).

Ecosystem disservices (EDS): "functions of ecosystems that are perceived as negative for human well-being" (Lyytimäki and Sipila, 2009).

Ecosystem-related human health outcomes: the final health endpoints impacted by both beneficial and adverse effects of (changes in) ecosystems, using the same categories as the WHO's global burden of disease study (Mathers and Stevens, 2013). Examples of what we considered as health outcomes in our review are: diseases, injuries, behavioral disorders and mortality. Proximal health determinants (e.g., access to clean air or clean water, shelter and availability of sufficient nutritious food) were not considered health outcomes.

Health-related ecosystem services (or disservices): ecosystem services (or disservices) that positively (or negatively) affect health outcomes, either directly or indirectly.

Human health: "a state of complete physical, mental and social well-being and not merely the absence of disease or infirmity" (WHO, 2006). The MA (2005a) defines human health similarly and adds "The health of a whole community or population is reflected in measurements of disease incidence and prevalence, age-specific death rates, and life expectancy".

Human well-being: "a context- and situation-dependent state, comprising basic material for a good life, freedom and choice, health and bodily well-being, good social relations, security, peace of mind, and spiritual experience" (MA, 2005a).

Tools: (semi-)automated aids in conducting an assessment of ecosystem impacts on human health. In practice, this concerns digital, computer-based tools, such as models, interactive maps, databases and toolkits. We restricted our review to ecosystem-based tools, i.e., tools using qualitative ecosystem characteristics or quantitative parameters (e.g., type, state, area) as inputs.

Box 2-Key aspects of the complexity of the ecosystem-human health relation.

1. Multiple drivers of ecosystem change: Changes in climate, land use and resource availability drive ecosystem changes and the impacts of these drivers on ecosystem services can also change over time (Forget and Lebel, 2001; Huynen et al., 2005; Myers et al., 2013; Reis et al., 2013).

2. Long and complex cause-effect chains: The cause-effect chains between driver, ecosystem condition and human health are often long, long-term and complex, due to nonlinearity and feedback loops (Briggs, 2008; Corvalan et al., 2005; Coutts et al., 2014; Forget and Lebel, 2001; Hartig et al., 2014; Huynen et al., 2005; Jackson et al., 2013; MA, 2005c; Myers et al., 2013; Webb et al., 2010).

3. Multiple and diverse health impacts: Degradation of a specific ecosystem type can produce several very different health outcomes (Briggs, 2008; Corvalan et al., 2005; Hartig et al., 2014; Myers et al., 2013). Forest conversion for example, can cause an increase in infectious diseases, malnutrition and mental disorders (Myers et al., 2013).

4. Ecosystem services as well as disservices: Ecosystems providing a health service preventing one particular disease can at the same time provide a health disservice enhancing another disease. Moreover, whilst some ecosystems provide a health service concerning a particular disease, other ecosystems could provide a health disservice for the same disease (Briggs, 2008; Hartig et al., 2014; Myers et al., 2013; Reis et al., 2013). This is illustrated in Fig. 2.

5. Spatial heterogeneity and multi-scalarity: The health outcomes associated with a particular ecosystem change (or a driver of change) can differ from location to location, and the underlying mechanisms as well. Some of these health impacts can be observed across one or several regions of the world, whilst others occur only locally. Moreover, global drivers of ecosystem change can have local health impacts and vice versa (Briggs, 2008; Corvalan et al., 2005; Forget and Lebel, 2001; Keune et al., 2013a; MA, 2005c; Myers et al., 2013).

6. Interaction with socio-economic factors: Socio-economic factors are not only important health determinants themselves, but can also buffer or enhance the impact of ecosystems on human health (Briggs, 2008; Coutts et al., 2014; Forget \& Lebel, 2001; Hartig et al., 2014; Huynen et al., 2005; Myers et al., 2013; Reis et al., 2013; Webb et al., 2010). 
of ecosystem impacts on human health is also increasingly being recognized by researchers in other fields such as ecology and biology (e.g., Keesing and Ostfeld, 2015; Sandifer et al., 2015), social sciences (e.g., Henke and Petropoulos, 2013; Trochim et al., 2006) and more interdisciplinary fields such as environmental, sustainability and other interdisciplinary scientists (e.g., Coutts et al., 2014; Jackson et al., 2013; Keune et al., 2013a; Reis et al., 2013). Many of these researchers explicitly acknowledge the complexity of the ecosystem-human health relationship and the need to take this into account. For example, Soskolne et al. (2007) state that epidemiologists "must embrace greater complexity, including long time scales, complex dynamics and diverse causal pathways associated with disruptions in the natural systems underpinning health. The traditionally used, reductionist, linear approaches are inferior for understanding the interactive webs that are critical for sustainable development and for the health and well-being of future generations".

To cope with the complexity of the ecosystem-human health relationship in assessment of health impacts, computer-based tools such as models, interactive maps and toolkits (for example sets of specific methods and databases), can be an important aid. Several reviews are available on assessment tools for ecosystem services that provide benefits to human well-being in general (Bagstad et al., 2013; Crossman et al., 2013; Peh et al., 2013; UNEP (2008a; 2008b), but thus far no review has been published of tools that can be used to assess specifically the impacts of (changing) ecosystems on human health. Responding to this gap, the aim of this review is to assess to what extent existing ecosystem assessment tools can aid in assessing ecosystem impacts on health. Given the importance of such tools in addressing the complexity of the ecosystem-human health relationship, we expect that the results of our review will be indicative of the current capacity to assess ecosystem impacts on health.

In the next section, we present the conceptual underpinning of the tool review, including definitions of key terms and an overview of direct health-related ecosystem services and disservices. In the following section, we explain our methods of identifying, selecting and evaluating relevant assessment tools and summarize the results. Details on both methods and results are given in the appendices. In the final section, we present the conclusions, discuss major findings and end with an outlook on further tool development, including recommendations.

\section{How ecosystems and human health are linked}

In this section, we provide the conceptual foundation for the tool review, consisting of definitions of key terms (Box 1), a conceptual framework for the assessment of ecosystem impacts on health, and an overview of relevant ecosystem services and disservices with associated health outcomes.

\subsection{Dealing with complexity in ecosystem-human health assessment}

Scientists addressing the ecosystem-human health relationship often mention several aspects characterizing the complexity of this relation (e.g., Briggs, 2008; Corvalan et al., 2005; Coutts et al., 2014; Forget and Lebel, 2001; Hartig et al., 2014; Myers et al., 2013; Reis et al., 2013). Most of these aspects are similar across publications. Box 2 provides an overview of key aspects that characterize and contribute to the complexity of the ecosystem-human health relationship. Listed are those aspects considered by the authors as important to address in assessments. In our conceptual framework for assessment of ecosystem impacts on human health (Fig. 1), we have indicated how and where these complexity aspects can be accounted for in an assessment.

Fig. 1 indicates how the main components of the ecosystem-health relationship can be related in an assessment of ecosystem impacts on human health. It builds on the framework of Myers et al. (2013), which explicitly focuses on the ecosystem-health relationship and emphasizes the multiple layers of social or infrastructural factors that can buffer or eliminate health risks. In the conceptual framework, drivers of change alter the state of ecosystems and their (dis)services, and this subsequently affects one or more human health outcomes. However, the eventual impact of the new ecosystem state on human health is co-determined by multiple layers of social or infrastructural factors. This chain from drivers to health outcomes can be assessed for ecosystem services (with a positive impact on human health) as well as ecosystem disservices (with a negative impact on health). In Fig. 1, the multiple health-related ecosystem services and disservices are represented with green and red 'tabs', respectively. It is also indicated in

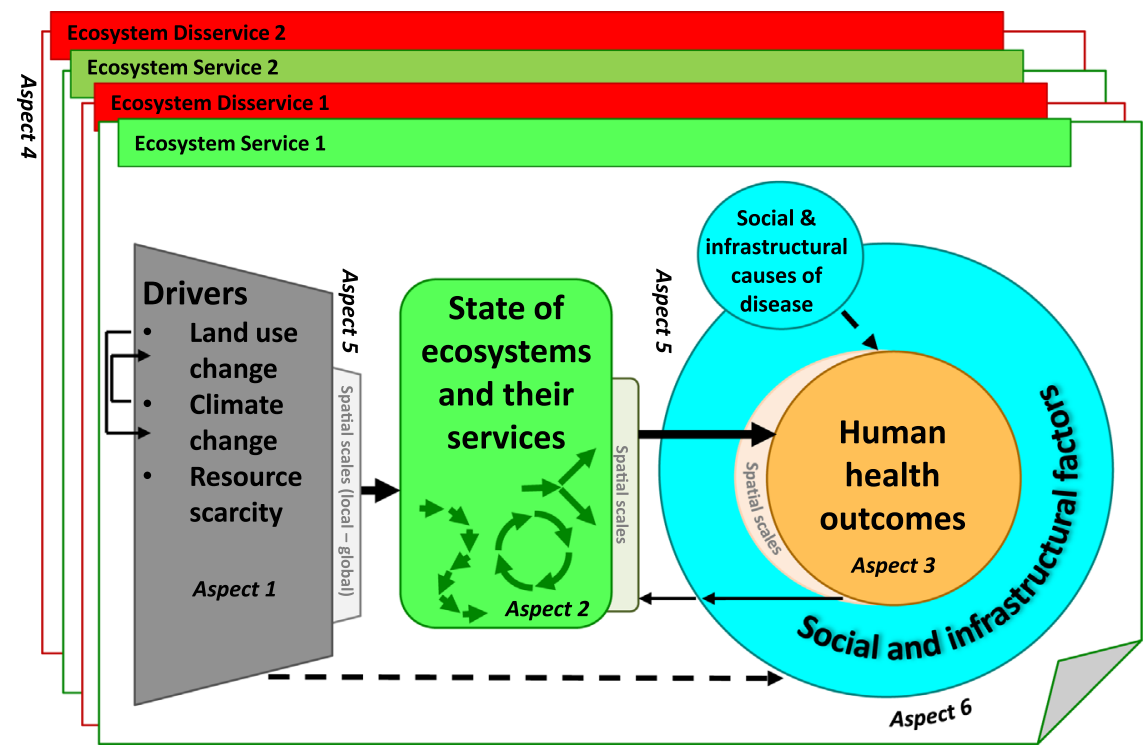

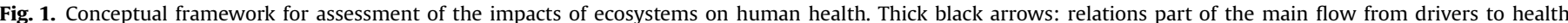

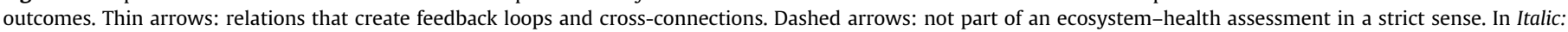

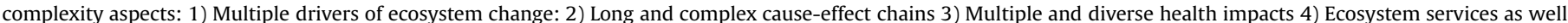
as disservices 5) Spatial heterogeneity and multi-scalarity 6) Interaction with socio-economicfactors. Adapted from Myers et al. (2013). 

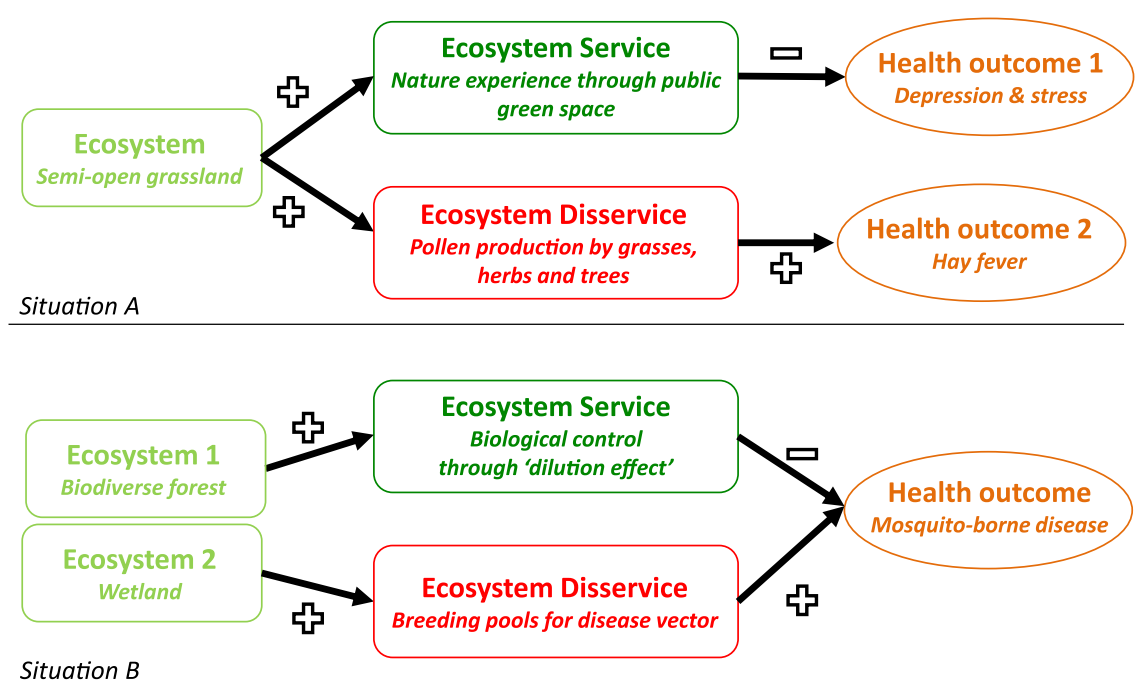

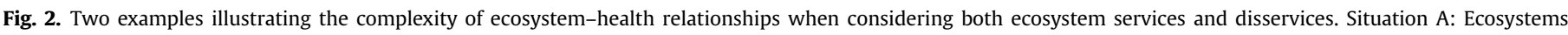

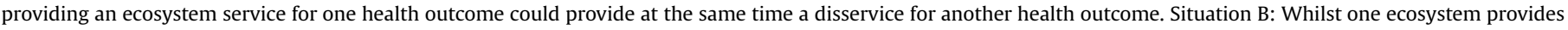
an ecosystem service concerning a particular disease, another ecosystem could provide a disservice concerning the same disease.

the framework which aspects of complexity of the ecosystem-human health relationship play a key role and where. The objectives of an assessment will determine on which complexity aspects will be focused, which ecosystems, health outcomes, etc. Examples of such objectives are to calculate the health burden currently avoided or created for a specific disease, to forecast disease burden trends, to quantify the health impacts of planned land-use changes, to meet certain health targets, or to evaluate trade-offs between different land management options. Ecosystem (dis)service processes are not included in the framework of Fig. 1. A diagram and overview useful for structurally mapping and process-based modeling ecosystem services are already provided through the ES cascade framework (HainesYoung and Potschin, 2010; Maes et al., 2012) and the blueprint for mapping and modeling ES (Crossman et al., 2013).

\subsection{Services, disservices and health outcomes}

The frequently used framework of the MA links the different categories of ecosystem services (supporting, provisional, regulating and cultural) to human well-being (MA, 2003, 2005a, 2005c, 2005d), providing a rough indication about to what degree each category of ecosystem services (ES) affects the different constituents of well-being. ES are acknowledged by the MA as having an effect on the following human health constituents of well-being: 'strength', 'feeling well' and 'access to clean air and water'. The MA indicates a strong link between regulating or provisioning services and human health, as well as a weaker link between cultural services and health (Corvalan et al., 2005; MA, 2005c). However, the MA does not provide a comprehensive overview of specific health-related ES per category of well-being, nor does it provide lists of specific human health outcomes related to ES. Furthermore, ecosystem disservices (EDS) are not considered at all in the MA reports, except that concerning infectious disease is stated that "the magnitude and direction of altered disease incidence due to ecosystem changes depend on the particular ecosystems" (Patz and Confalonieri, 2005). As a starting point for our tool review, we therefore first performed a literature search to obtain a comprehensive

Table 1

Direct health-related ecosystem services.

\begin{tabular}{|c|c|}
\hline Ecosystem services & Sources \\
\hline \multicolumn{2}{|l|}{ Provisioning } \\
\hline Provision of food & $\begin{array}{l}\text { Corvalan et al. (2005), MA (2005c), Myers and Patz (2009), Levy et al. (2012), Jackson et al. (2013), Keune et al. (2013b), } \\
\text { WHO and CBD Secretariat (2015) }\end{array}$ \\
\hline Provision of medicinal resources & MA (2005c), Keune et al. (2013b), WHO and CBD Secretariat (2015) \\
\hline Provision of timber, fiber and fuel & Corvalan et al. (2005), MA (2005c), Jackson et al. (2013) \\
\hline \multicolumn{2}{|l|}{ Regulating } \\
\hline Air purification & Myers and Patz (2009), Jackson et al. (2013), Keune et al. (2013b), WHO and CBD Secretariat (2015) \\
\hline Climate stabilization (cooling) & $\begin{array}{l}\text { Corvalan et al. (2005), MA (2005c), Myers and Patz (2009), Levy et al. (2012), Jackson et al. (2013), WHO and CBD Secre- } \\
\text { tariat (2015) }\end{array}$ \\
\hline Biological control of infectious diseases & MA (2005c), Myers and Patz (2009), Levy et al. (2012), Keune et al. (2013b), WHO and CBD Secretariat (2015) \\
\hline Environmental microbial diversity & WHO and CBD Secretariat (2015) \\
\hline Noise reduction & Turkelboom et al. (2013), Liekens et al. (2013) \\
\hline Protection from natural hazards & Myers and Patz (2009), Levy et al. (2012), Jackson et al. (2013), Keune et al. (2013b), WHO and CBD Secretariat (2015) \\
\hline $\begin{array}{l}\text { Waste management, processing and } \\
\text { detoxification }\end{array}$ & Corvalan et al. (2005), MA (2005c) \\
\hline Water purification & $\begin{array}{l}\text { Corvalan et al. (2005), MA (2005c), Myers and Patz (2009), Levy et al. (2012), Jackson et al. (2013), Keune et al. (2013b), } \\
\text { WHO and CBD Secretariat (2015) }\end{array}$ \\
\hline \multicolumn{2}{|r|}{ 10. } \\
\hline $\begin{array}{l}\text { Promotion of social interactions and cul- } \\
\text { tural traditions }\end{array}$ & Corvalan et al. (2005), MA (2005c), WHO and CBD Secretariat (2015) \\
\hline Recreation and nature experience & Corvalan et al. (2005), MA (2005c), Jackson et al. (2013), Keune et al. (2013b), WHO and CBD Secretariat (2015) \\
\hline Provision of esthetic environments & Jackson et al. (2013), WHO and CBD Secretariat (2015) \\
\hline
\end{tabular}


overview of health-related ES and EDS.

\subsubsection{Health-related ecosystem services}

More general and not health-specific ES classifications, including the EU CICES classification, contain ES that are more specific for health. Examples are the ES 'Provision of medicinal resources' or 'Provision of genetic materials' (EEA, 2015; UK-NEA, 2015; Wittmer et al., 2012), 'Disease regulation', 'Biological control' or 'Pest and disease control' (EEA, 2015; UK-NEA, 2015; Wittmer et al., 2012) and 'Recreation and mental and physical health' (Wittmer et al., 2012). Several literature sources present lists, classifications or overviews specifically of health-related ES (Corvalan et al., 2005; Jackson et al., 2013; Keune et al., 2013b; Levy et al., 2012; MA, 2005c; Myers and Patz, 2009; WHO and CBD Secretariat, 2015). We used these sources to create a comprehensive list of direct health-related ES. We merged and combined ES that were identical or similar. For example, we regarded air filtration, air purification and clean air as the same service and combined buffering of floods and droughts with protection from natural hazards. The distinction 'direct' versus 'indirect' for ES and biodiversity-health pathways has been made often, but many sources use their own criteria (for example see Asah et al., 2014; Clarke, 2014; Crossman et al., 2013; Fisher et al., 2009). For the sake of composing a comprehensive list of direct health-related ES, we defined indirect health-related ES as affecting human health only through another service (or disservice). We excluded this type of ES from our ES list and tool review. This was the case for ES 'Biological control of invasive species' (affects amongst others the services of biological control of infectious diseases and recreation and nature experience), 'Habitat maintenance and biodiversity' (that leads to several other services including recreational services), 'Nutrient management' (affects food provision and waste management) and 'Pollination' (that leads to several other services including food provision). The ES 'Climate stabilization' will also impact other direct health-related ES, such as 'Biological control of infectious diseases', 'Protection from natural hazards' and 'Recreation and nature experience'. However, it also affects human health in direct ways, for example by reducing heat stress (Sari Kovats and Hajat, 2008). This procedure resulted in a list of 14 ES with a direct relation to human health (Table 1 ).

\subsubsection{Health-related ecosystem disservices}

The concept of EDS is rather new. Only recently the functions of ecosystems that are perceived as negative to human well-being have been put under the umbrella of EDS. Von Döhren and Haase (2015) found 103 journal publications in which the term 'ecosystem' and 'disservice' were used in relation to each other, the majority of which was published after 2009. The concept of EDS is somewhat contested. Shapiro and Báldi (2014), for example, argued that there is no need for this new concept, as "many ecosystem disservices have always been acknowledged and accounted for (...)", whereas Villa et al. (2014b) expressed their fear that the concept of EDS "hampers, rather than helps, the development of an integrative and constructive dialog about conservation" and "adds confusion as nascent efforts emerge to tackle the long-standing goal of understanding and quantifying the dynamic aspects of ecosystem services (...)". Lyytimäki (2015) counter-argued: "The core question of the concept of EDS is not about highlighting the disservices per se, but about putting both ecosystem services and disservices under a common assessment framework. This is required in order to establish a comprehensive overview of the net effects of ecosystem functions for human well-being". Following this line of argumentation, we included EDS in our tool review.

Most studies on EDS have been conducted in agricultural and urban (forest) ecosystems in Western Europe or the United States (Von Döhren and Haase, 2015). Several publications focus on both ES and EDS, but only few of them focus on the full range of EDS of one or several ecosystem types. As the concept of EDS was only recently introduced, many publications about health risks from ecosystems do not use this term. To our knowledge, no publications exist that aim to provide an overview of EDS affecting human health specifically. In order to obtain an overview of health-related EDS, we therefore reviewed the 22 unique results through Google Scholar and Web of Science with the terms 'ecosystem' and 'disservice' or 'disservices' in the title, and identified eight healthrelated EDS. We then excluded the indirect health-related EDS, i.e., when an EDS affects human health only through another disservice (or service). This concerned the EDS of promoting invasive species (Escobedo et al., 2011; Gilioli et al., 2014), which impacts health through other EDS by being a source of infectious diseases and bringing about negative psychological effects, or by being a source of pests of crops, hampering the food provision ES. Also the EDS of 'hosting pests' itself (Destefano and Deblinger, 2005; O'Farrell et al., 2007; Zhang et al., 2007) was considered as indirect, as it affects human health through the service of food provision. This resulted in six direct health-related EDS (Table 2).

\subsubsection{Health outcomes}

Through our literature search, we identified fourteen direct healthrelated ES and six EDS directly affecting human health, but most sources did not specify which human health outcomes are affected by these ES and EDS. To clarify the connections to health outcomes, we therefore provide for each ES and EDS several examples of associated health outcomes (Table 3), in terms of WHO health categories (Mathers and Stevens, 2013). The table aims to be comprehensive concerning main linkages described in literature, but is not exhaustive concerning sources referred to. This overview shows that several ES and EDS affect the same health categories, but in opposite ways. However, in the case of the health category of 'injuries', the type of injury prevented by ES often differs from that caused by EDS.

Table 2

Direct health-related ecosystem disservices.

\begin{tabular}{|c|c|}
\hline Ecosystem disservices & Sources \\
\hline Increased prevalence of allergens & $\begin{array}{l}\text { Lyytimäki et al. (2008), Lyytimäki \& Sipila (2009), Escobedo et al. (2011), } \\
\text { Dobbs et al. (2014), Von Döhren and Haase (2015) }\end{array}$ \\
\hline $\begin{array}{l}\text { Inhibiting human safety (e.g., falling branches, collisions with animals, dangerous wild } \\
\text { animals, plant protection mechanisms, forest fires) }\end{array}$ & $\begin{array}{l}\text { Lyytimäki et al. (2008), Lyytimäki and Sipila (2009), Escobedo et al. (2011), } \\
\text { Lyytimäki (2014), Von Döhren and Haase (2015) }\end{array}$ \\
\hline Source of infectious diseases & Lyytimäki et al. (2008), Escobedo et al. (2011), Von Döhren and Haase (2015) \\
\hline Decreasing air quality & Escobedo et al. (2011), Von Döhren and Haase (2015) \\
\hline Decreasing water quality and/or quantity & Lyytimäki (2014), Von Döhren and Haase (2015) \\
\hline $\begin{array}{l}\text { Bringing about negative psychological effects (through sounds, smells, behavior of plants/ } \\
\text { animals, or dense vegetation) }\end{array}$ & $\begin{array}{l}\text { Lyytimäki et al. (2008), Lyytimäki and Sipila (2009), Escobedo et al. (2011), } \\
\text { Lyytimäki (2014), Von Döhren and Haase (2015) }\end{array}$ \\
\hline
\end{tabular}

a The listed sources include studies on non-pathological effects, such as fear and anxiety. 
Table 3

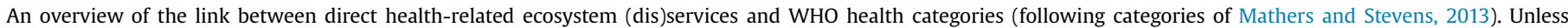

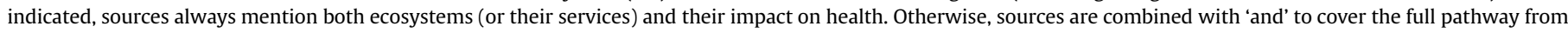
ecosystems to health. Adapted from the reviews of Jackson et al. (2013) and Sandifer et al. (2015).

\begin{tabular}{lll}
\hline Direct ecosystem (dis)services & WHO health categories & Sources
\end{tabular}

Ecosystem Service (decreases the disease burden)

Air purification

-Neonatal conditions

-Malignant neoplasms

-Mental and behavioral disorders

-Cardiovascular diseases

Water purification

Climate stabilization
Protection from natural hazards
Biological control of infectious
diseases

Recreation and nature experience

Waste management, processing and detoxification

Provision of food

Provision of medicinal resources

Provision of timber, fiber and fuel

Provision of esthetic environments

Environmental microbial diversity

Noise reduction

Promotion of social interactions and cultural traditions

Ecosystem Disservice (increases the
Increased prevalence of allergens
Inhibiting human safety

Source of infectious diseases

Decreasing air quality

Decreasing water quality and/or quantity

Bringing about negative psychological effects
-Respiratory diseases

-Infectious and parasitic diseases

-Neonatal conditions

-Malignant neoplasms

-Mental and behavioral disorders

-Genitourinary diseases

-Injuries (poisoning)

-Injuries (heat stroke, heat exhaustion etc.)

-Mental and behavioral disorders

-Infectious and parasitic diseases

-Mental and behavioral disorders

-Respiratory diseases

-Injuries (drowning, poisoning)

-Infectious and parasitic diseases

-Neonatal conditions

-Mental and behavioral disorders

-Cardiovascular diseases (and obesity)

-Infectious diseases

-Malignant neoplasms

-Neurological conditions

-Respiratory diseases

-Nutritional deficiencies

-Infectious and parasitic diseases

Several diseases for which medicine and therapy can be improved

No sources found that link ecosystems

to specific health outcomes.

-Mental and behavioral disorders

-Diabetes mellitus

-Malignant neoplasms

-Diabetes mellitus

-Endocrine, blood, immune disorders

-Mental and behavioral disorders

-Respiratory diseases

-Digestive diseases

-Cardiovascular diseases

-Sense organ diseases

-Mental and behavioral disorders -General mental and physical health outcomes of social impacts

-Mental and behavioral disorders e burden)

-Respiratory diseases

-Injuries (drowning, road injuries,

poisoning and burn injuries )

-Infectious and parasitic diseases

-Respiratory diseases

No sources found that link to specific health outcomes.

-Mental and behavioral disorders
-Injuries (poisoning)
Dadvand et al. (2012), Escobedo and Nowak (2009) and Wu et al. (2009) Bealey et al. (2007) and Pope et al. (2002)

Escobedo and Nowak (2009) and Brook et al. (2009)

Escobedo and Nowak (2009) and Prescott et al. (1998), Bealey et al. (2007) and Miller et al. (2007)

Powe and Willis (2004), Dadvand et al. (2012), Nowak et al. (2014)

UNEP (2008a; 2008b)

Budd et al. (2009) and Eskenazi et al. (2004), Budd et al. (2009) and Villanueva et al., (2005)

Khan et al. (2009) and Beaumont et al. (2008), Schoonover et al., (2005) and

Ward et al. (2010)

Khan et al. (2009) and Bouchard et al. (2007)

Khan et al. (2009) and Jarup et al. (2000)

UNEP (2008a; 2008b), Khan et al. (2009) and Araya et al. (2004)

Armson et al. (2012) and Sari Kovats and Hajat (2008), Boumans et al. (2014)

Armson et al. (2012) and Hansen et al. (2008)

Bravo de Guenni (2005), Ming et al. (2007) and Ivers and Ryan (2006)

Ming et al. (2007) and Gruebner et al. (2015), Ming et al. (2007) and Reacher et al. (2004)

Ming et al. (2007) and Reacher et al. (2004)

Bravo de Guenni (2005), McIvor et al. (2012), Ming et al. (2007) and Hajat et al. (2005), Ming et al. (2007) and Wade et al. (2004)

Patz and Confalonieri (2005), Dobson et al. (2006), Pongsiri et al. (2009),

Keesing et al. (2010), Derne et al. (2011), Laporta et al. (2013), Keesing and Ostfeld (2015)

Donovan et al. (2011)

Curtin (2009), Barton and Pretty (2010), Lottrup et al. (2013), Song et al. (2014), Wheeler et al.(2015), Bratman et al. (2015)

Nielsen and Hansen (2007), Wolch et al. (2011), Pereira et al. (2013), Dhaliwal et al. (2013), Astell-Burt et al. (2014)

Corvalan et al. (2005), Hinga and Batchelor (2005)

Corvalan et al. (2005), Hinga and Batchelor (2005)

Hinga and Batchelor (2005)

Hinga and Batchelor (2005)

Hinga and Batchelor (2005)

Chaplin-Kramer et al. (2014), Ellis et al. (2015), Ellis et al. (2015)

Ellis et al. (2015)

Chivian and Bernstein (2008), Kettunen et al., (2009), Bernstein (2014)

WEHAB (2002), Liddell and Morris (2010) - these sources address health (and social) aspects

Sugiyama et al. (2008), Maas et al. (2009), Honold et al. (2015), Kardan et al. (2015)

Astell-Burt et al. (2014)

von Hertzen et al., (2011b)

von Hertzen et al., (2011a)

Rook (2013), Rook et al. (2014), von Hertzen et al., (2011a)

Rook et al. (2014) and Valkanova et al. (2013)

Hanski et al. (2012), Ruokolainen et al., (2015)

Timm et al. (2014)

Gomez-Baggethun and Barton (2013) and Münzel et al. (2014)

Gómez-Baggethun and Barton (2013), Mendonça de Carvalho (2013), Derk-

zen et al. (2015)

Gómez-Baggethun \& Barton (2013) and Den Boer and Schroten (2007)

Albrecht et al. (2007), WHO and CBD Secretariat (2015) - these sources address the link from ecosystems to social impacts, but not specific effects on health outcomes

MA (2005b) and Alston and Kent (2004)

Arnold (2012), Lovasi et al. (2013), Fuertes et al. (2014)

WHO (2007), Tomalak et al. (2011), Barua et al. (2013), Faustini et al. (2015), Jin et al. (2015), Sahani et al. (2014)

Douglas (2012), Wood and Lafferty (2013), Valle and Clark (2013), States et al. (2014)

Pataki et al. (2011), Roy et al. (2012), Baró et al. (2014)

Pataki et al. (2011), Roy et al. (2012), Burgin et al.(2013) - these sources address ecosystem aspects

Jadhav and Barua (2012), Barua et al. (2013) 
Box 3-The eleven organizations contacted during the search for ecosystem tools

- Belgian Community of Practice on Biodiversity and Health - http://www.biodiversity.be/health/

- Canadian Community of Practice in Ecosystem Approaches to Health (CoPEH-Canada) - http://www.copeh-canada.org/

- Centre for Health and the Global Environment at Harvard Medical School - http://www.chgeharvard.org/

- Co-operation on Health and Biodiversity (COHAB) - http://www.cohabnet.org/

- EcoHealth Alliance - http://www.ecohealthalliance.org/

- Ecosystem-Based Management (EBM) Tools Network - http://www.natureserve.org/conservation-tools/ecosystem-based-management-tools-network

- Ecosystem Service Partnership (Working Groups 'Ecosystem Services and Public Health', 'Modeling ES' and 'Mapping ES') - http://www.es-partnership.org/

- European Centre for Environment and Human Health - http://www.ecehh.org/

- Health and Ecosystems: analysis of linkages (HEAL) cooperation - http://www.wcs-heal.org/

- Sub-Global Assessment Network - http://www.ecosystemassessments.net

- United States Environmental Protection Agency (several health and ecosystem researchers contacted) - http://www2.epa.gov/healthresearch 
Table 4

Tool inclusion and exclusion criteria.

Tool inclusion criteria (search criteria)

$\begin{array}{ll}\text { Title, abstract or full text contain } & \begin{array}{l}\text { Combinations of keywords for ES/EDS, assessment/monitoring, human health, health-related ES/EDS, tools, health outcomes } \\ \text { and ecosystem parameters }\end{array} \\ \text { or relevant organizations recommend } & \text { Documented tool as 'addressing the ecosystem-human health relationship' }\end{array}$

Tool exclusion criteria (applied to initial search results)

\author{
Tool type \\ or main target user group is not \\ or documentation does not expose \\ or documentation does not refer to \\ or documented tool is \\ or documented tool is \\ or documented tool is
}

\author{
Is not a digital, computer-based tool \\ (Health, ecosystem or other) researchers, (policy) decision makers, land use planners or natural resource managers, ecologists \\ or health professionals (such as general practitioners) \\ Use of ecosystem parameters in the tool \\ Ecosystem-related health outcomes, health proxies / risk factors or health-related ecosystem (dis)services that could be ad- \\ dressed by the tool \\ Location-specific (not generalizable) \\ Not developed or still under construction to the extent that it is not executable \\ Only available after payment or not available to researchers and institutions working in the ecosystem - human health field
}

\section{Tools to analyze the ecosystem-human health relation}

In this section we present our tool review. After explaining the selection and evaluation procedures, we provide an overview of the results.

\subsection{Methods: tool search, selection and evaluation}

In our review of tools for assessing the ecosystem-human health relationship, we applied two types of criteria: tool search and selection criteria to find and select the most relevant tools and tool evaluation criteria to determine their strong and weak points.

\subsubsection{Tool search and selection criteria}

We aimed to identify assessment tools that provide insight into how (changes in) the type and state of ecosystems impacts human health. For our review, we searched for tools in two ways: (1) by using the search engines of Web of Science and Google Scholar, (2) by contacting eleven organizations that focus on the relation between ecosystems and human well-being or health. In the latter case, we asked the contacts of these organizations which tools, tool documentation or promising methods related to the ecosystemhuman health theme they provide, use or know of. The organizations that we contacted are listed in Box 3. In a later stage, we also contacted a person involved in the tool development process for each tool that passed our selection criteria (Appendix B), to ask if they could recommend tools for the same purpose.

For our systematic literature search through the search engines, we constructed five main keyword sets related to ecosystems, ecosystem services and disservices, human health, tools, and assessment. We then combined these keyword sets in search queries in order to find ecosystem tool documentation. The search was limited to English language journal articles and reports, published from January 1990 to September 2015. As the concepts of ES and especially EDS are relatively new, it might be expected that in many cases these terms will not be used in documentation of tools that assess the impact of ecosystems on human well-being. Therefore we chose to include alternative keyword combinations to represent ES and EDS. Several ecosystem service tool overviews (such as Bagstad et al., 2013; Crossman et al., 2013; MartínezHarms and Balvanera, 2012) indicate that many tools that address ES and/or EDS impacts on human well-being, are not designed to address human health specifically. Therefore, we also considered tools when the ES and/or EDS treated in a tool can partially be related to health outcomes, or when the tool provides outcomes that can be regarded as health risk factors or health proxies. In accordance with the aim of this review, we focused on finding relevant ecosystem-based tools. We were therefore quite flexible regarding the health dimension and quite strict regarding the ecosystem dimension of the ecosystem-health relationship in our tool search. For example, during our literature search, we required an ecosystem-related keyword in the title of publications, but for human health related keywords, substitution by health-related $\mathrm{E}$ (D)S keywords was allowed under certain conditions. (See Appendix A for a detailed description of the literature search method, as well as the protocol we used to contact organizations.)

After performing our search for tool documentation, we narrowed down the search results based on several exclusion criteria to include only those tools that focus on ES and/or EDS, either explicitly or implicitly. This included a criterion that tool documentation or tool usage had to show its applicability to more than only a few sites, landscapes or regions. One way to achieve this (especially in the case of maps) is a large spatial extent covering multiple countries or states. Another, for tools addressing smaller scales, is the possibility for the user to select the location, which might be any location in the world, within a given, large area or within certain ecosystem types. Bagstad et al. (2013) refer to the second type as 'generalizable tools'.

Table 4 presents an overview of all tool inclusion and exclusion criteria. For a more elaborate explanation of the tool inclusion criteria, exclusion criteria and the use of search queries and keywords, see Appendix A.

\subsubsection{Tool characteristics and evaluation criteria}

After characterizing the selected tools in terms of tool type, objective, intended users and type of output, we evaluated the tools according to six criteria (Box 4). Where multiple (dis)services were included in a tool, we focused on those directly affecting human health. The six evaluation criteria were based on the key aspects of the complexity of the ecosystem-health relationship (Box 2), because the potential usefulness of assessment tools rests specifically on their capacity to take these complexity aspects into account. For most of the criteria, the sub-criteria only partially address the corresponding complexity aspect, because we did not expect full coverage given the early stage of development of ecosystem service tools. Moreover, a computer-based tool will often not be the only method employed to perform an assessment. Guidance on how to deal with complexity aspects that are not included in the tool could be included in the tool documentation. For the evaluation, we made use of tool documentation from articles, reports and on the tool's official website, performed a tool test run of components related to ES affecting human health and made use of existing general ES tool reviews. Finally, we also established contact with at least one tool developer of each tool, to ask for their feedback on our preliminary tool evaluation results. (For more information on the tool evaluation method and sources used for 
Box 4-Tool evaluation criteria and sub-criteria.

\section{Inclusion of drivers of ecosystem change}

- Extent to which relevant drivers such as climate change, land use change and changes in resource availability are included

- Extent to which the magnitude of their (changing) impact is clarified or approximated

2. Representation of processes in the ecosystem-health relation, including drivers of ecosystem change

- Representation of important aspects of relevant (complex) cause-effect chains

- Extent to which ecosystem parameters are used and possible interconnecting factors between $E(D) S$

- Quantification and handling of uncertainty

3. Suitability for assessment of how ecosystems affect human health

- Number of health-related E(D)S in the tool and possible expression in a common health unit

- Health outcomes (diseases, health benefits) or links to health outcomes and their role in the tool

- Health-related tool development plans: tool potential to asses human health in the future

4. Inclusion of ecosystem services as well as disservices

- Whether or not the tool allows for assessment of both services and disservices.

- Addressing in tool or documentation of both services and disservices of one ecosystem, or human well-being outcomes to which some ecosystems attribute a service whilst other ecosystems attribute a disservice

- Explicit attention in tool or documentation for the balance of ES and EDS

5. Multi-scalarity

- Generalizability: the degree to which the tool can be applied to different locations, such as different ecosystems or different regions. Similar description used as Bagstad et al. (2013).

- Spatial scalability: the spatial scale-levels for which the model can be used: site, local/landscape/watershed, national, regional, continental or global. Similar description used as Bagstad et al. (2013). If not scalable: whether the model is suitable for the continental or global scale.

- Ability to address multiple scales. Possible inter-/extrapolation or aggregation capacity from smaller to larger scale.

6. Attention for interacting socio-economic factors

- Addressing in tool or documentation of socio-economic factors that buffer or enhance ecosystem impacts

- Providing an idea in tool or documentation of the fraction that socio-economic factors contribute to health outcomes as compared to the ecosystem-related factors 
Table 5

Objectives of evaluated tools (as described in tool documentation).

\begin{tabular}{|c|c|c|c|c|c|c|}
\hline Name & $\begin{array}{l}\text { Quantify ecosystem } \\
\text { services } \\
\text { (biophysically) }\end{array}$ & $\begin{array}{l}\text { Express the eco- } \\
\text { nomic value of } \\
\text { ecosystem } \\
\text { services }\end{array}$ & $\begin{array}{l}\text { Choose between } \\
\text { land management } \\
\text { options (trade-offs) }\end{array}$ & $\begin{array}{l}\text { Forecast change in } \\
\text { ecosystem service } \\
\text { provision (trends } \\
\text { scenarios) }\end{array}$ & $\begin{array}{l}\text { Explore the linkages } \\
\text { between ecosystem al- } \\
\text { teration, ES and human } \\
\text { well-being (congruence) }\end{array}$ & $\begin{array}{l}\text { Serve as data portal for } \\
\text { storage, visualization } \\
\text { and sharing of methods, } \\
\text { maps and other data }\end{array}$ \\
\hline i-Tree Eco & $\mathrm{X}$ & $\mathrm{X}$ & & & & \\
\hline ARIES & $\mathrm{X}$ & $\mathrm{X}$ & $\mathrm{X}$ & $\mathrm{X}$ & & \\
\hline InVEST & $\mathrm{X}$ & $\mathrm{X}$ & $\mathrm{X}$ & & & \\
\hline MIMES & $\mathrm{X}$ & $\mathrm{X}$ & & $\mathrm{X}$ & $\mathrm{X}$ & \\
\hline SolVES & $\mathrm{X}$ & & & & & \\
\hline $\begin{array}{l}\text { EnviroAtlas Inter- } \\
\text { active Map }\end{array}$ & $\mathrm{X}$ & & & & & $X$ \\
\hline $\begin{array}{r}\text { Coastal Resilience } \\
\text { mapping portal }\end{array}$ & $\mathrm{X}$ & & & & & \\
\hline TESSA & & $\mathrm{X}$ & & & $\mathrm{X}$ & \\
\hline $\begin{array}{l}\text { Green Infrastructure } \\
\text { Valuation Toolkit }\end{array}$ & $\mathrm{X}$ & $\mathrm{X}$ & & & & \\
\hline $\begin{array}{l}\text { Eco-Health Relation- } \\
\text { ship Browser }\end{array}$ & & & & & $\mathrm{X}$ & $\mathrm{X}$ \\
\hline TEEB-stad tool & $\mathrm{X}$ & $\mathrm{X}$ & & & $\mathrm{X}$ & \\
\hline Total & $\underline{9}$ & $\underline{7}$ & $\underline{2}$ & $\underline{2}$ & $\underline{4}$ & $\underline{2}$ \\
\hline
\end{tabular}

evaluation, see Appendix C.)

\subsection{Results: tool selection, characteristics and evaluation}

Here, we first present our tool search and selection results, and describe the tool types and objectives. In subsequent sections, we then present the tool evaluation results for each criterion separately following the order of the criteria in Box 4. For detailed descriptions and evaluation results per tool, see Appendix C.

\subsubsection{Tools for the ecosystem-human health relation}

Our extensive search resulted in a set of 40 potential tools (see Appendix B). Most organizations and developers (20 out of 22) responded to our call for potential tools. Nineteen tools were found in the literature search, whilst 26 were identified by contacting relevant organizations or tool developers. After application of our exclusion criteria, 11 tools were selected for our review. Five of the selected tools are models: i-Tree Eco (UNDPA, 2015), ARIES (Villa et al., 2014a), InVEST (Tallis and Polasky, 2009), MIMES (Boumans et al., 2015) and SolVES (Sherrouse et al., 2011). Two tools are interactive (geographic) maps: the EnviroAtlas Interactive Map (Pickard et al., 2015) and the Coastal Resilience mapping portal (The Nature Conservancy, 2015). Two are (quite different) toolkits: TESSA (Peh et al., 2013) and the Green Infrastructure Valuation Toolkit (Natural Economy Northwest, ,2014). Finally, we selected the 'Eco-Health Relationship Browser' interactive framework (Jackson et al., 2013) and the 'TEEB-stad' ('TEEB-city') benefit quantification tool (Van Dijk et al., 2013). There are large differences between the tools in terms of objectives, spatial scale, or output. Also, most of these tools were not specifically constructed to assess human health effects of ecosystems. Next to a terrestrial application, several of the models also contain marine modules or their documentation addresses marine applications (Bagstad et al., 2011; Boumans et al., 2015; Sharp et al., 2015). Appendix C provides a detailed overview of the health-related ES addressed per tool, tool characteristics and tool performance against our evaluation criteria. In the appendix, we also list the core tool publications (when available) and the official websites where tools can be executed, viewed or downloaded, or where the tool documentation or manual can be downloaded. We used these as main sources for our evaluation. We also received and included feedback from tool developers of each tool on our preliminary tool evaluation results (see Appendix C). We used almost all of this feedback to correct errors and to identify future tool development.

\subsubsection{Tool objectives}

The objectives of the tools selected for evaluation (Table 5) are diverse, but most focus on quantification of ES in biophysical terms and on monetary valuation of ES. Determining ecosystem impacts on human health is not an explicit objective of any of these tools, except for the qualitative Eco-Health Relationship Browser. Many tools focus on a monetary output, especially the models where this is often linked to assessment of trade-offs between ES. Among the quantitative tools, MIMES is the only with the primary objective to explore the dynamics of ES (by simulating biophysical processes). Egoh et al. (2012) identified two additional possible ES study purposes: understanding costs (next to benefits) and identifying priorities. These seem to be a less explicit purpose of the evaluated tools.

The documentation of the reviewed tools often mentions decision makers, government agencies and land use planners as intended tool users. Typical tool objectives for these target users could be the quantification of health impacts currently avoided or created, quantification of the change in health impacts through planned land-use changes, or evaluation of trade-offs taking into account human well-being. These objectives are related to objective one, three and four of Table 5 respectively. Other health-related objectives that these target users might have are to meet certain health or well-being targets or to maximize well-being. Such objectives were never mentioned in tool documentation, and would require reasoning 'in the opposite direction': from human well-being outcomes to ecosystems or ecosystem changes.

\subsubsection{Criterion 1: inclusion or documentation of drivers of ecosystem change}

Relevant drivers for ecosystem change, such as changes in climate, land use and resource availability, are often partially included in the models that we reviewed or in their documentation. The MIMES model is able to perform analyses of dynamic climate and land use change scenarios based on the feedbacks between its components. For ARIES, InVEST and SolVES, the effect of drivers of change can be assessed by running the model several times with different input scenarios of land use or climate change and then comparing the results 'manually'. Both ARIES and InVEST will be upgraded to automate this comparative analysis (see Appendix C). The interactive map tools allow for overlaying of ES maps with some 'driver' maps, such as map layers with socio-economic or sea level rise data. However, the derivation of possible relationships with ES is up to the tool user. 
Table 6

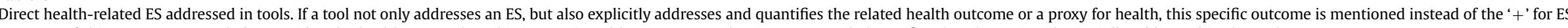
presence. If this outcome can only be considered a health proxy, then this is mentioned between parentheses. A ' \pm ' symbol signifies that the ES is only partially addressed in the tool.

\begin{tabular}{|c|c|c|c|c|c|c|c|c|c|}
\hline Name & $\underline{\text { Air }}_{\text {purification }}$ & $\begin{array}{l}\text { Water pur } \\
\text { ification }\end{array}$ & Climate stabilization & $\begin{array}{l}\text { Protection from nat- } \\
\text { ural hazards }\end{array}$ & $\begin{array}{l}\text { Recreation and } \\
\text { nature experience }\end{array}$ & $\begin{array}{l}\text { Waste management, proces- } \\
\text { sing and detoxification }\end{array}$ & $\begin{array}{l}\text { Provision } \\
\text { of food }\end{array}$ & $\begin{array}{l}\text { Provision of timber, } \\
\text { fiber and fuel }\end{array}$ & $\begin{array}{l}\text { r,Provision of es- } \\
\text { thetic } \\
\text { environments }\end{array}$ \\
\hline i-Tree Eco & $\begin{array}{l}\text { Respiratory } \\
\text { diseases }\end{array}$ & \pm & + & \pm & & \pm & & & \\
\hline ARIES & & + & + & + & + & & + & & + \\
\hline InVEST & & & + & $\begin{array}{l}\text { (Relative vulnerability } \\
\text { to coastal storms) }\end{array}$ & + & & + & & + \\
\hline MIMES & + & + & $\begin{array}{l}\text { Heat-related morbidity and mortality, re- } \\
\text { spiratory \& cardiovascular diseases }\end{array}$ & + & + & + & + & & + \\
\hline SolVES & & & & & + & & & & + \\
\hline $\begin{array}{l}\text { EnviroAtlas Inter- } \\
\text { active Map }\end{array}$ & $\begin{array}{l}\text { Respiratory } \\
\text { diseases }\end{array}$ & + & + & + & + & & + & + & + \\
\hline $\begin{array}{r}\text { Coastal Resilience } \\
\text { mapping portal }\end{array}$ & & & & $\begin{array}{l}\text { (Population at flood } \\
\text { risk) }\end{array}$ & & & & & \\
\hline TESSA & & & + & + & + & & & + & \\
\hline $\begin{array}{l}\text { Green Infrastructure } \\
\text { Valuation Toolkit }\end{array}$ & + & + & + & + & Mortality & & & & \\
\hline $\begin{array}{l}\text { Eco-Health Relation- } \\
\text { ship Browser }\end{array}$ & + & + & & + & + & & & & + \\
\hline TEEB-stad tool & $\begin{array}{l}\text { (Reduced } \\
\text { health costs) }\end{array}$ & & & + & $\begin{array}{l}\text { (Reduced physician } \\
\text { visits) }\end{array}$ & \pm & & & \pm \\
\hline Total & $\underline{6}$ & $\underline{5}$ & $\underline{7}$ & $\underline{9}$ & $\underline{9}$ & $\underline{1}$ & $\underline{4}$ & $\underline{2}$ & $\underline{6}$ \\
\hline
\end{tabular}




\subsubsection{Criterion 2: representation of processes from driver to human} health outcome

Except for the Eco-Health Relationship Browser, all evaluated tools explicitly aim to quantify ES and are able to do this. All five models focus on quantifying the underlying cause-effect chain from ecosystem processes to ES. The method to do this varies. i-Tree Eco covers cause-effect chains from ecosystem to human health fully and step-by-step, for example, from urban forest abundance via pollutant removal to avoided respiratory disease. Pollution, weather and population data are used to determine actual ES supply. Most other models distinguish between ES supply and demand more explicitly. InVEST uses spatially-explicit calculations representing ecological production functions to quantify biophysical outputs. The level of ecosystem-service demand is also estimated in most of the InVEST models. ARIES has a more elaborate mechanistic approach in the sense that besides supply and demand, also possible ES flow is modeled explicitly, as well as sinks on ES flow paths. However, where data is insufficient, probabilistic relationships are used instead. MIMES can model actual supply based on demand profiles of different human user groups (Boumans et al., 2015). The model can be considered as having the most comprehensive simulation of the mechanisms underlying the complete driver - ecosystem - ES chain, considering its 'earth spheres approach' within a 'coupled humannatural system', including exchange and feedbacks between the spheres. The SolVES model takes a completely different approach by analyzing social survey response data and generating maps based on that. The two interactive maps provide readymade ES map outputs that can be overlaid with maps containing supplementary biophysical data. However, it is up to the user to derive possible relationships between the ES and the biophysical factors. The other tools rely on straightforward calculations: biophysical and socio-economic input factors are combined with (socio-economic, biophysical, health) parameters with default values to produce biophysical values representing ES, which is followed by monetary valuation. MIMES and ARIES seem to be the only quantitative tools able to account for interaction between multiple health-related ecosystem-ES chains (see Appendix C).

In i-Tree Eco and the three most spatially explicit models (ARIES, InVEST, SolVES), the ecosystem parameters used are often ecosystem, habitat or vegetation cover, type and their characteristics (such as evapotranspiration and vegetation height). MIMES, one of the most mechanistic models, uses ecosystem processes such as nutrient flows, primary production, biomass production per ecosystem type, and predator-prey relations. The interactive map tools use mapped ecosystem parameters such as habitat type (mangrove, coral reef, oyster reef). The other quantitative tools use type of vegetation cover and vegetation characteristics. In most tools, the relationships between ecosystem parameters and ES are determined separately, without interaction between ES.

\subsubsection{Criterion 3: suitability for assessment of how ecosystems affect human health}

Most of the 11 direct health-related ES are included in one or more of the evaluated tools (Table 6). ES that are most often included are 'Protection from natural hazards' (floods and storms are included, not droughts) and 'Recreation and nature experience'. 'Waste management, processing and detoxification' is often not included as separate ES, but is partially addressed in some tools through the mechanism of avoided wastewater treatment through increased water storage capacity. The ES 'Provision of medicinal resources', 'Biological control of infectious diseases', 'Noise reduction', 'Environmental microbial diversity' and 'Promotion of social interactions and cultural traditions' are not included in any of the evaluated tools. The (limited) extent of current EDS inclusion in tools will be treated as separate criterion below.
We identified four tools that include explicit and quantitative links to human health outcomes. Two of them include links to respiratory disease. The i-Tree Eco tool makes this specific link in the most comprehensive way, including health impact functions. In i-Tree Eco, the ES 'Air purification' is linked to respiratory diseases through EPA's Environmental Benefits Mapping and Analysis Program (BenMAP) and corresponding tool. BenMAP is also available as a separate tool to assess the effects of pollutants on health (Fann et al., 2009; Tagaris et al., 2009). EnviroAtlas Interactive Map is also able to display several indicators of reduced respiratory diseases. Other ecosystem-related health outcomes generated are reduced mortality related to the ES 'Recreation and nature experience' and heat-related morbidity and mortality related to the ES 'Climate stabilization', both in a separate tool. Three other tools are able to generate health proxy values. Two tools link the ES 'Protection from natural hazards' through indicators like 'vulnerability' and 'population at risk'. However, the explicit link in these tools to, for example, cases of drowning, waterborne diseases or mental disorders is not made. The TEEB-stad tool estimates reduced health costs through reduction in particulate matter by vegetation. It also estimates reduced physician visits through urban greening. However, actual diseases or other health outcomes are not addressed in the TEEB-stad tool or its documentation. The qualitative Eco-Health Relationship Browser provides argumentation and a large number of references for several links between ES and health outcomes.

For several of the selected tools, components that produce more health proxies are planned or under development (i-Tree Eco, ARIES, InVEST, TESSA; see Appendix $C$ for more details). Moreover, for other tools components are planned that specifically address human health outcomes. For the MIMES model, human health is the major development focus and several components are planned, such as on biological control of infectious diseases. The TEEB-stad tool is being developed to be more explicit about health outcomes, such as mental disorders. Components addressing negative links between ecosystems and health are planned as well for some tools and will be treated below.

\subsubsection{Criterion 4: inclusion or documentation of EDS}

None of the tools included in our review explicitly addresses healthrelated EDS. However, some of the evaluated models do implicitly include EDS processes. This is most developed in i-Tree Eco. In this model, the EDS 'Decreasing air quality' (e.g., through bio-emission) of VOCs) is accounted for in the tool's component for the ES 'Air purification', which makes i-Tree the only selected tool able to generate ES values corrected for EDS processes. For ARIES, ecosystem processes that reduce ES are incorporated in ES modules through modeling them as 'sinks' in the ES flow dynamics. Regarding MIMES, some of its production functions produce a result that might be perceived as a disservice by stakeholders. A final observation is that also in tool documentation, EDS possibly associated with the ES addressed in a tool, are not explicitly mentioned. However, this might change, because several tool developers consider inclusion of EDS in both the documentation and the tool itself (TESSA, Green Infrastructure Valuation Toolkit, Eco-Health Relationship Browser, see Appendix C). Example EDSs that are planned are the potential of trees to increase local pollutant concentrations and the production of pollen. There are currently models available that simulate pollen dispersal and deposition (e.g., Bunting and Middleton, 2005; Duffin and Bunting, 2008). However they have not been linked in tool or tool documentation to human well-being aspects or health proxies, such as a specific focus on allergenic species. This might change in the near future (Arnold, 2012).

\subsubsection{Criterion 5: multi-scalarity}

The i-Tree, InVEST, ARIES and MIMES models are generalizable with respect to the particular area to be assessed. However, this does require the user to acquire (additional) data for the area of interest. The same applies to the TESSA toolkit. The map tools 
(EnviroAtlas Interactive Map and Coastal Resilience mapping portal) provide data with near-continental and global coverage respectively. All other evaluated tools (including the SolVES model) can also be applied to different areas. However, for these tools the user must first check whether the tool uses parameter and index values taken from a specific location or country and whether the conditions for the area of interest are similar enough. If not, these parameter values should be adapted, which all tools, except for TEEB-stad, allow (but which is not always recommended in tool documentation).

The ARIES, InVEST and MIMES models are able to process and/or produce data on the landscape-global scale or the landscape-regional scale. SolVES is built to address the watershed or landscape scale. Both map tools (EnviroAtlas Interactive Map, Coastal Resilience mapping portal) follow a two-scale approach. However, for the smaller scale (for which more data and more detailed data is available) only a limited selection of particular areas is available. Whether the Eco-Health Relationship Browser is useful for a certain area and scale of interest depends on ES-Health relations selected and scientific evidence provided for that link. The toolkits and the 'TEEB-stad' benefit analysis tool are especially designed for the local-landscape scale. Although some tools can work with data of multiple spatial scales, most models will only use that part of the data that falls within the user-specified area of interest. None of the tools is designed to interpolate or extrapolate data or results to other scales.

\subsubsection{Criterion 6: attention for interacting socio-economic factors}

All models include interactions with socio-economic factors to some extent, mostly by means of a human population data set. The interactive maps allow overlaying of core map results with data on socio-economic factors (and EnviroAtlas Interactive Map will make additional socioeconomic data available in the future, Appendix C), but it is up to the user to derive possible relationships between these factors and ES. The TESSA Toolkit developers plan to include the socio-economic dimension in future releases. The other quantitative tools include several separate social and economic factors (such as 'yearly air-conditioner use' and 'length of recreational routes'). However, none of the tools appears to be able to separately calculate the contribution of the socio-economic factors to an $\mathrm{E}(\mathrm{D}) \mathrm{S}$, and to compare this with the ecosystem contribution. A minor exception is the Coastal Resilience mapping portal's feature to assess the combined and individual effect of natural and artificial structures (dike, artificial reef) on flood risk. However, it can only do this for a limited number of regions.

\section{Conclusions, discussion and outlook}

\subsection{Conclusions}

In the literature, we identified fourteen direct health-related ES and six EDS. We then conducted an extensive search for computer-based assessment tools for these ES and EDS. This resulted in a selection of eleven tools for further evaluation: five models, two interactive maps, two toolkits, one interactive framework and one benefit quantification tool. Most of the direct health-related ES are addressed in one or more of the evaluated tools. Five of the fourteen health-related ES are not included in any of the quantitative tools. More importantly, determining human health outcomes is not the primary objective of any of the quantitative tools, and there are major shortcomings regarding the links to health outcomes. Only in the 'Eco-Health Relationship Browser' interactive framework, many health outcomes of several ecosystem types are organized in an overview. Furthermore, two tools quantitatively included health outcomes of 'Air purification', of which one fully represented the pathway to respiratory disease. Specific health outcomes linked to the ES 'Climate stabilization' and 'Recreation and nature experience' are addressed in one tool each. None of the tools addressed more than one health outcome. Concerning the ES 'Protection from natural hazards', health proxies like flood and storm vulnerability are represented in a mapping as well as a modeling tool. Finally, the health proxies 'reduced health costs' related to the ES 'Air purification' and 'reduced physician visits' through the ES 'Recreation and nature experience' are addressed in one other tool. Only two quantitative tools were able to account for interaction between multiple health-related ecosystem-ES chains. Finally, none of the evaluated tools addresses explicitly one or more health-related EDS, although one tool (i-Tree Eco) implicitly takes the effect of the EDS 'Decreasing air quality' into account.

We also evaluated the extent to which the selected tools address key aspects of the complexity of the ecosystem - human health relationship. Each of the six major complexity aspects identified in the literature is at least basically addressed in one or more of the evaluated tools or tool documentation. However, none of these complexity aspects is addressed to the full extent (as defined in Box 2 and 4). Some tool developers indicated plans to further develop these aspects in the tool, especially concerning cause-effect chain components and incorporation of dynamic drivers of ecosystem change. None of the evaluated tools is able to separately include or calculate the effects of buffering or enhancing socio-economic factors. A minor exception is the Coastal Resilience mapping portal's feature to separately assess the effect of artificial structures on flood risk for a few regions. Moreover, only one of the tools is able to subtract EDS from ES. Overall, there appear to be trade-offs in tool capacity to deal with the various complexity aspects, most notably between inclusion of multiple health outcomes on the one hand and representation of ecosystem processes, inclusion of drivers and multi-scalarity on the other hand. With respect to the quantitative models, another trade-off was apparent, between multi-scalarity and representation of ecosystem processes and drivers. Currently, none of the evaluated tools address all six complexity aspects. Moreover, the tools covering the most complexity aspects are not the tools that focus the most on human health outcomes.

\subsection{Discussion}

The literature search method we applied resulted in a focus on tools with a scientific foundation. Therefore, we might have overlooked relevant tools that are not documented in scientific publications. However, as we also consulted major organizations that focus on the relation between ecosystems and human health, we expect that our final selection of 11 tools is highly representative of the current state-of-the-art in assessment of ecosystem impacts on health. This includes our findings that in these tools the link between ES and concrete health outcomes is only made to a limited extent, and that none of the tools explicitly addresses health-related EDS. The finding that the link to health outcomes in ES assessment tools is only made to a limited extent could be considered remarkable, since health is one of five wellbeing categories that the MA linked to ES and considerable attention was paid to this link (MA, 2005d). An explanation might be that health benefits from ecosystems, such as avoided healthcare costs, are more difficult to quantify than ecosystem benefits for which a market exists. Moreover, before a dollar value can be assigned to health impacts of ecosystems, various biophysical factors and disease burdens need to be quantified first. An explanation for the finding that none of the tools explicitly addresses EDS, might be that the need to also include the negative impacts of ecosystems on human well-being was only recently expressed by a few environmental scientists and ecologists (fore example Dunn, 2010; Escobedo et al., 2011; Lyytimäki and Sipila, 2009) and health scientists (e.g., Briggs, 2008; Myers et al., 2013).

Yet, the absence of EDS tools in our selection is especially remarkable for the case of infectious diseases, as these have a very large global disease burden of $16 \%$ (WHO, 2014). Furthermore, there is not 
only an absence of tools on how ecosystems stimulate infectious disease, but also of tools that include the ES 'Biological control of infectious disease'. Several environmental scientists and ecologists have emphasized that ecosystems play an important role in regulating the transmission of many infectious diseases (Mace et al., 2005) and can even reduce disease prevalence (Becker et al., 2014; et al., Keesing et al., 2010; Keesing and Ostfeld, 2015; Keune et al., 2013a). Both the relevance of ecosystem parameters in tools to estimate the infectious disease burden and methods and data available to include these factors have been described (Beck et al., 2000; Ceccato et al., 2005; Stresman, 2010). However, there is no consensus on the general direction of disease incidence following ecosystem changes, as this depends on location and circumstances (Lafferty and Wood, 2013; Mace et al., 2005; Randolph and Dobson, 2012; Valle and Clark, 2013; Wood and Lafferty, 2013). Several literature sources do indeed describe methods to link land use change or disease vector habitat availability to an increase of specific infectious diseases, but without generalizing the method for other locations (see methods described in Ahmad et al., 2011; Eisele et al., 2003; Mischler et al., 2012; Nmor et al., 2013; Stryker and Bomblies, 2012). Also, many tools for infectious diseases that are generalizable or large-scale include vector population parameters, but do not include ES or ecosystem parameters. Examples of such tools are models and maps for the infectious diseases of malaria and schistosomiasis (see models and maps described by Craig et al. (1999), De Oliveira Duarte et al. (2014), Githeko et al. (2014), Jones and Morse (2009), Martens et al. (1999), Patil et al. (2011), Project (2015), Sinka et al. (2011), Van Lieshout et al. (2004). Following our selection criteria, we did not include these methods and tools in our review.

A final issue to consider is whether other definitions of key terms (Box 1) might have led to a different selection of tools. Especially the WHO's definition of human health has been criticized over the past decades. For example, it has been proposed to change its emphasis towards "the ability to adapt and self manage in the face of social, physical, and emotional challenges" (Huber et al., 2011). However, possible problems with the WHO definition as described by Huber et al. (2011), such as an unintentional contribution to the medicalization of society, are not relevant for our tool review. More generally, it seems unlikely that other definitions of health would have resulted in another selection of tools, as we only excluded tools that were not even remotely related to health (Table 4).

\subsection{Outlook}

To deal with important aspects of the complex relationship between ecosystems and human health, construction and/or further development of existing, computer-based assessment tools is needed. These needs must be considered in the context of an ecosystem-health assessment that combines a variety of methods, tools and knowledge sources. An assessment purely relying on computer-based tools is highly unrealistic, given the hard-toquantify cause-effect relationships for certain E(D)S and the hardto-model nature of complexity aspects for certain $E(D) S$. This is especially the case for health-related $\mathrm{E}(\mathrm{D}) \mathrm{S}$ for which modification by certain socio-economic factors is important. Ideally, the tool documentation should indicate which areas of uncertainty and complexity cannot be addressed by the tool and provide suggestions for complementary methods. Compared to these other methods, computer-based tools do have unique strengths however, and further development could contribute to better assessment of ecosystem impacts on health. In this respect, we recommend to focus on models, as this tool-type is most suitable to deal with both complexity and quantification. Especially spatially explicit models integrated with Geo-Information Systems (GIS) will be useful. A major reason is that this enables to deal with spatial complexity. In GIS, both the multi-scalarity of health-related $E(D) S$ and the difference in locations for supply and demand, relevant for several E(D)S, can be addressed. Another important reason is that spatially explicit models can generate maps, which are very useful for "spatially explicit prioritization and problem identification (...) Further, maps can be used as a communication tool to initiate discussions with stakeholders" (Maes et al., 2013). Developers of such tools should take into account important health objectives, such as meeting human well-being or health target values. These objectives require a tool to 'work in the opposite direction': using target values as input to derive the land use or green infrastructure changes required to reach the target. In other words, an optimization function.

For several of the reviewed tools, components that produce (more) specific health outcomes or additional health proxies are planned or under development. The development of tools explicitly addressing EDS can also be expected in the near future, given the steep increase in publications on this issue in the past years. To speed up the development of these tools, we recommend the researchers involved to start or intensify collaborations with health scientists, health practitioners and the targeted end-users, such as decision makers and land use planners. As several health scientists publish about the ecosystem contribution to disease, willingness to build bridges seems to be there, although there is still a major difference in methodology between ecosystem scientists and health scientists. Soskolne et al. (2007) mention the linear, reductionist approaches of epidemiology and public health research in the second half of the 20th century, focusing on proximate cause-andeffect relationships. By training, epidemiologists and public health researchers are less accustomed to studying causes within a systems context or addressing long time frames (Martens and Huynen, 2003). Most health scientists will therefore not be familiar with the complex quantitative modeling approaches that are developed by ecosystem scientists. However, the past decade has seen a promising rise in interest in adopting more complex model approaches in health research (e.g., Galea et al., 2010; Mendez, 2010; Sterman, 2006; Trochim et al., 2006), and models can thus be a communication tool to develop a shared terminology between health and ecosystem scientists and form a basis for collaboration. In case of further tool development, we also recommend to search the 'health field' for already existing tools that contain fully developed health components and provide linkages with the ES (and EDS) addressed by the ecosystem-based tools. The i-Tree Eco tool provides an example of how ecosystem-based and healthbased tools can efficiently be combined: the ES 'Air purification' is linked to human health outcomes through another tool (BenMAP) that assesses the health impacts of pollutants.

Finally, we recommend a focus on development of tool components able to calculate the effect of socio-economic factors. Some developers of evaluated tools already plan to do so in the near future. This would enable a comparison between the contribution of socio-economic factors to health outcomes and the impact of ecosystem parameters. As mentioned earlier, aiming for an assessment tool that covers all aspects of the complex ecosystem-health relationship is unrealistic and even undesirable in our view. However, some of the key complexity aspects are more relevant than others: socio-economic factors will modify almost all ecosystem-health pathways, and inclusion of both ES and EDS is relevant for many cases (for example see Fig. 2). By combining incorporation of socio-economic factors with integration of EDS, a much better estimation could be made of the 'net impact' of ecosystems on human health. We expect this to substantially enhance the credibility of ecosystem assessments that include human health impacts to decision makers and stakeholders, and to thus promote the adoption of the ecosystem service concept in spatial planning.

\section{Acknowledgments}

We would like to recognize the contribution of several individuals involved with ecosystem tool development, who provided feedback or 
suggestions on tool evaluation: Kenneth J. Bagstad, Chris Bergh, Heleen Bothof, Roelof M.J. Boumans, Zach Ferdaña, Greg Guannel, Laura E. Jackson, Bonnie L. Keeler, Anne Neal, Paul Nolan, Kelvin S.H. Peh, Benson C. Sherrouse and Al Zelaya. Furthermore, we would like to thank Hedwig van Delden for providing feedback on an earlier draft version of this paper and two anonymous reviewers for helpful suggestions for improvement. Finally, we would like to thank several individuals affiliated with contacted organizations (see Box 3), who advised potential tools for review.

\section{Appendix A. Supplementary material}

Supplementary data associated with this article can be found in the online version at http://dx.doi.org/10.1016/j.ecoser.2015.12. 008.

\section{References}

Ahmad, R., Ali, W.N.W.M., Nor, Z.M., 2011. Mapping of mosquito breeding sites in malaria endemic areas in Pos Lenjang, Kuala Lipis, Pahang, Malaysia. Malar. J. 10, 361. http://dx.doi.org/10.1186/1475-2875-10-361.

Albrecht, G., Sartore, G.M., Connor, L., Higginbotham, N., Freeman, S., Kelly, B. Pollard, G., 2007. Solastalgia: the distress caused by environmental change. Australas. Psychiatry 15 (Suppl 1:S95-8). http://dx.doi.org/10.1080/ 10398560701701288

Alston, M., Kent, J., 2004. Social Impacts of Drought-A report to NSW Agriculture. Centre for Rural Social Research-Charles Sturt University, Wagga Wagga, pp. 87-92.

Araya, M. Olivares, M., Pizarro, F, Llanos, A, Figueroa, G, Uauy, R, 2004 Community-based randomized double-blind study of gastrointestinal effects and copper exposure in drinking water. Environ. Health. Perspect. 112 (10), 1068-1073.

Armson, D., Stringer, P., Ennos, A.R., 2012. The effect of tree shade and grass on surface and globe temperatures in an urban area. Urban For. Urban Green. 11 (3), 245-255. http://dx.doi.org/10.1016/j.ufug.2012.05.002

Arnold, E., 2012. Pollution-load zones of allergenic tree pollen in Boston (master thesis).

Arya, N., Howard, J., Isaacs, S., McAllister, M., Murphy, S., Rapport, D., WaltnerToews, D., 2009. Time for an ecosystem approach to public health? Lessons from two infectious disease outbreaks in Canada. Glob. Public Health 4, 31-49.

Asah, S.T., Guerry, A.D., Blahna, D.J., Lawler, J.J., 2014. Perception, acquisition and use of ecosystem services: Human behavior, and ecosystem management and policy implications. Ecosyst. Serv. 10, 180-186. http://dx.doi.org/10.1016/j. ecoser.2014.08.003.

Astell-Burt, T., Feng, X., Kolt, G.S., 2014. Is neighborhood green space associated with a lower risk of Type 2 diabetes? Evidence from 267,072 australians. Diabetes Care 37 (1), 197-201. http://dx.doi.org/10.2337/dc13-1325.

Bagstad, K.J., Semmens, D.J., \& Waage, S. (2013). A comparative assessment of decision-support tools for ecosystem services quantification and valuation. EcosystemServices, 5(e27-e39).

Barton, J., Pretty, J., 2010. What is the best dose of nature and green exercise for improving mental health? a multi-study analysis. Environ. Sci. Technol. 44 (10), 3947-3955. http://dx.doi.org/10.1021/es903183r.

Barua, M., Bhagwat, S.A., Jadhav, S., 2013. The hidden dimensions of humanwildlife conflict: health impacts, opportunity and transaction costs. Biol. Conserv. 157, 309-316. http://dx.doi.org/10.1016/j.biocon.2012.07.014.

Bealey, W.J., McDonald, A.G., Nemitz, E., Donovan, R., Dragosits, U., Duffy, T.R. Fowler, D., 2007. Estimating the reduction of urban PM10 concentrations by trees within an environmental information system for planners. J. Environ. Manag. 85 (1), 44-58. http://dx.doi.org/10.1016/j.jenvman.2006.07.007.

Beaumont, J.J., Sedman, R.M., Reynolds, S.D., Sherman, C.D., Li, L.H., Howd, R.A., Alexeeff, G.V., 2008. Cancer mortality in a Chinese population exposed to hexavalent chromium in drinking water. Epidemiology 19 (1), 12-23. http://dx doi.org/10.1097/EDE.0b013e31815cea4c.

Beck, L.R., Lobitz, B.M., Wood, B.L., 2000. Remote sensing and human health: new sensors and new opportunities. Emerg. Infect. Dis. 6 (3), 217-227. http://dx.doi. org/10.3201/eid0603.000301.

Becker, C.G., Rodriguez, D., Toledo, L.F., Longo, A.V., Lambertini, C., Corrêa, D.T., Zamudio, K.R., 2014. Partitioning the net effect of host diversity on an emerging amphibian pathogen (Vol. 281)

Bernstein, A.S., 2014. Biological diversity and public health. Ann. Rev. Public Health 35, 153-167. http://dx.doi.org/10.1146/annurev-publhealth-032013-182348.

Bouchard, M., Laforest, F., Vandelac, L., Bellinger, D., Mergler, D., 2007. Hair manganese and hyperactive behaviors: pilot study of school-age children exposed through tap water. Environ. Health Perspect. 115 (1), 122-127. http://dx.doi. org/10.1289/ehp.9504.

Boumans, R., Roman, J., Altman, I., Kaufman, L., 2015. The Multiscale Integrated
Model of Ecosystem Services (MIMES): Simulating the interactions of coupled human and natural systems. Ecosyst. Serv. 12 (0), 30-41. http://dx.doi.org 10.1016/j.ecoser.2015.01.004

Boumans, R.J.M., Phillips, D.L., \& Victery, W. (2014). Developing a model for effects of climate change on human health and health-environment interactions: Heat stress in Austin, Texas. Urban Climate, 8, 78-99.

Bratman, G.N., Hamilton, J.P., Hahn, K.S., Daily, G.C., Gross, J.J., 2015. Nature experience reduces rumination and subgenual prefrontal cortex activation. Proc. Natl. Acad. Sci. 112 (28), 8567-8572. http://dx.doi.org/10.1073/ pnas.1510459112.

Bravo de Guenni, L., 2005. Regulation of Natural Hazards: Floods and Fires. In: Hassan, R., Scholes, R., Ash, N. (Eds.), Ecosystems and Human Well-being: Current State and Trends 1. Island Press, Washington DC.

Briggs, D.J., 2008. A framework for integrated environmental health impact assessment of systemic risks. Environ. Health 7 (61), 252-253.

Brook, R.D., Urch, B., Dvonch, J.T., Bard, R.L., Speck, M., Keeler, G., Brook, J.R., 2009. Insights into the mechanisms and mediators of the effects of air pollution exposure on blood pressure and vascular function in healthy humans. Hypertension 54 (3), 659-667. http://dx.doi.org/10.1161/ hypertensionaha.109.130237.

Budd, R., O'Geen, A., Goh, K.S., Bondarenko, S., Gan, J., 2009. Efficacy of constructed wetlands in pesticide removal from tailwaters in the Central Valley, California. Env. Sci. Technol. 43 (8), 2925-2930.

Bunting, M.J., Middleton, D., 2005. Modelling pollen dispersal and deposition using HUMPOL software, including simulating windroses and irregular lakes. Rev. Palaeobot. Palynol. 134 (3-4), 185-196. http://dx.doi.org/10.1016/j. revpalbo.2004.12.009.

Burgin, A.J., Lazar, J.G., Groffman, P.M., Gold, A.J., Kellogg, D.Q., 2013. Balancing nitrogen retention ecosystem services and greenhouse gas disservices at the landscape scale. Ecol. Eng. 56, 26-35. http://dx.doi.org/10.1016/j. ecoleng.2012.05.003.

Baró, F., Chaparro, L., Gómez-Baggethun, E., Langemeyer, J., Nowak, D.J., Terradas, J., 2014. Contribution of ecosystem services to air quality and climate change mitigation policies: the case of urban forests in Barcelona, Spain. Ambio 43 (4), 466-479. http://dx.doi.org/10.1007/s13280-014-0507-x.

Bagstad, K.J., Villa, F., Johnson, G., \& Voigt, B. (2011). ARIES ARtificial Intelligence for Ecosystem Services-A guide to models and data (version 1.0. ARIES report series n.1. ed.): The ARIES Consortium.

Ceccato, P., Connor, S.J., Jeanne, I., Thomson, M.C., 2005. Application of Geographical Information Systems and Remote Sensing technologies for assessing and monitoring malaria risk Parassitologia. Vol. 47, pp. 81-96.

Chaplin-Kramer, R., Dombeck, E., Gerber, J., Knuth, K.A., Mueller, N.D., Mueller, M., Klein, A.-M., 2014. Global malnutrition overlaps with pollinator-dependent micronutrient production. Proc. R. Soc. Lond. B: Biol. Sci. 281, 1794. http://dx. doi.org/10.1098/rspb.2014.1799.

Chivian, E., Bernstein, A., 2008. Sustaining Life: How Human Health Depends on Biodiversity. Oxford University Press, Inc, New York.

Clarke, L.W., 2014. The Biodiversity and Direct Ecosystem Services and Disservices of Urban Gardens. University of California.

Corvalan, C., Hales, S., Woodward, A., 2005. Chopra, K., Leemans, R., Kumar, P., Simons, H. (Eds.), Consequences and Options for Human Health Volume 3. Ecosystems and Human Well-being: Policy Responses, Washington DC.

Coutts, C.J., Forkink, A., Weiner, J., 2014. The portrayal of natural environment in the evolution of the ecological public health paradigm. Int. J. Environ. Res. Public Health 11 (1), 1005-1019.

Craig, M.H., Snow, R.W., Le Sueur, D., 1999. A Climate-based distribution model of malaria transmission in Sub-Saharan Africa. Parasitol. Today 15 (3), 105-111.

Crossman, N.D., Burkhard, B., \& Nedkov, S. (2013). A blueprint for mapping and modelling ecosystem services. Ecosystem Services, 4, 4-14.

Curtin, S., 2009. Wildlife tourism: the intangible, psychological benefits of humanwildlife encounters. Curr. Issues Tour. 12 (5-6), 451-474. http://dx.doi.org/ $10.1080 / 13683500903042857$.

Dadvand, P., de Nazelle, A., Triguero-Mas, M., Schembari, A., Cirach, M., Amoly, E., Nieuwenhuijsen, M., 2012. Surrounding greenness and exposure to air pollution during pregnancy: an analysis of personal monitoring data. Environ. Health Perspect. 120, 1286-1290.

De Oliveira Duarte, H., Lopez Droguett, E., Das Chagas Moura, M., 2014. An ecological model for quantitative risk assessment for schistosomiasis: the case of a patchy environment in the Coastal Tropical Area of Northeastern Brazil. Risk Anal. 34 (5), 831-846.

Den Boer, L.C., Schroten, A., 2007. Traffic noise reduction in Europe-Health effects, social costs and technical and policy options to reduce road and rail traffic noise: CE Delft.

Derkzen, M.L., van Teeffelen, A.J.A., Verburg, P.H., 2015. REVIEW: quantifying urban ecosystem services based on high-resolution data of urban green space: an assessment for Rotterdam, the Netherlands. J. Appl. Ecol. 52 (4), 1020-1032. http://dx.doi.org/10.1111/1365-2664.12469.

Derne, B.T., Fearnley, E.J., Lau, C.L., Paynter, S., Weinstein, P., 2011. Biodiversity and leptospirosis risk: a case of pathogen regulation? Med. Hypotheses 77 (3), 339-344. http://dx.doi.org/10.1016/j.mehy.2011.05.009.

Destefano, S., Deblinger, R., 2005. Wildlife as valuable natural resources vs. intolerable pests: a suburban wildlife management model. Urban Ecosyst. 8 (2) 179-190. http://dx.doi.org/10.1007/s11252-005-4379-5.

Dhaliwal, S.S., Welborn, T.A., Howat, P.A., 2013. Recreational physical activity as an independent predictor of multivariable cardiovascular disease risk. PLoS ONE 8 (12), e83435. http://dx.doi.org/10.1371/journal.pone.0083435. 
Dobbs, C., Kendal, D., \& Nitschke, C.R. (2014). Multiple ecosystem services and disservices of the urban forest establishing their connections with landscape structure and sociodemographics. Ecological Indicators, 43(0), 44-55. doi: 10.1016/j.ecolind.2014.02.007.

Dobson, A., Cattadori, I., Holt, R.D., 2006. Sacred cows and Symphathetic Squirrels: The Importance of Biological Diversity to Human Health. PLoS Med. 3 (6), e231. http://dx.doi.org/10.1371/journal.ped.0030231.

Donovan, G.H., Michael, Y.L., Butry, D.T., Sullivan, A.D., Chase, J.M., 2011. Urban trees and the risk of poor birth outcomes. . Health Place 17 (1), 390-393. http://dx. doi.org/10.1016/j.healthplace.2010.11.004.

Douglas, I., 2012. Urban ecology and urban ecosystems: understanding the links to human health and well-being. Curr. Opin. Environ. Sustain. 4 (4), 385-392. http://dx.doi.org/10.1016/j.cosust.2012.07.005.

Duffin, K., Bunting, M.J., 2008. Relative pollen productivity and fall speed estimates for southern African savanna taxa. Veget. Hist. Archaeobot. 17 (5), 507-525. http://dx.doi.org/10.1007/s00334-007-0101-2.

Dunn, R.R., 2010. Global mapping of ecosystem disservices: the unspoken reality that nature sometimes kills us. Biotropica 42 (5), 555-557.

EEA. (2015). Common International Classification of Ecosystem Services (CICES). 2015, from 〈http://biodiversity.europa.eu/maes/common-international-classifi

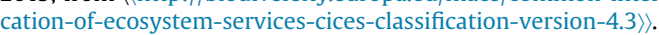

Egoh, B., Drakou, E.G., Dunbar, M.B., Maes, J., Willemen, L., 2012. Indicators for mapping ecosystem services: a review JRC scientific and policy reports (version 1.0. ARIES report series n.1. ed.): European Commission, Joint Research Centre, Institute for Environment and Sustainability.

Eisele, T.P., Keating, J., Swalm, C., 2003. Linking field-based ecological data with remotely sensed data using a geographic information system in two malaria endemic urban areas of Kenya. Malaria Journal, 2(44). doi: doi:10.1186/14752875-2-44.

Ellis, A.M., Myers, S.S., Ricketts, T.H., 2015. Do pollinators contribute to nutritional health? PLoS ONE 10 (1), e114805. http://dx.doi.org/10.1371/journal. pone.0114805.

Escobedo, F.J., Kroeger, T., Wagner, J.E., 2011. Urban forests and pollution mitigation: analyzing ecosystem services and disservices. Environ. Pollut. 159, 2078-2087. http://dx.doi.org/10.1016/j.envpol.2011.01.010.

Escobedo, F.J., Nowak, D.J., 2009. Spatial heterogeneity and air pollution removal by an urban forest. Landsc. Urban Plan. 90 (3-4), 102-110. http://dx.doi.org 10.1016/j.landurbplan.2008.10.021.

Eskenazi, B., Harley, K., Bradman, A., Weltzien, E., Jewell, N.P., Barr, D.B., Holland, N. T., 2004. Association of in utero organophosphate pesticide exposure and fetal growth and length of gestation in an agricultural population. Env. Health Perspect. 112 (10), 1116-1124.

Fann, F., Fulcher, C., Hubbell, B., 2009. The influence of location, source, and emission type in estimates of the human health benefits of reducing a ton of air pollution. Air Qual. Atmos. Health 2 (3), 169-176. http://dx.doi.org/10.1007/ s11869-009-0044-0.

Faustini, A., Alessandrini, E.R, Pey, J., Perez, N., Samoli, E., Querol, X., group, t.M.-P.s. 2015. Short-term effects of particulate matter on mortality during forest fires in Southern Europe: results of the MED-PARTICLES Project. Occup. Environ. Med. 72 (5), 323-329. http://dx.doi.org/10.1136/oemed-2014-102459.

Fisher, B., Turner, R.K., \& Morling, P. (2009). Defining and classifying ecosystem services for decision making. Ecological Economics, 68(3), 643-653. doi: 10.1016/j.ecolecon.2008.09.014.

Forget, G., \& Lebel, J. (2001). An Ecosystem Approach to Human Health. International Journal of Occupational and Environmental Health, 7(2).

Fuertes, E., Butland, B.K., Ross Anderson, H., Carlsten, C., Strachan, D.P., Brauer, M., 2014. Childhood intermittent and persistent rhinitis prevalence and climate and vegetation: a global ecologic analysis. Ann. Allergy, Asthma Immunol. 113 (4), 386-392. http://dx.doi.org/10.1016/j.anai.2014.06.021.

Galea, S., Riddle, M., \& Kaplan, G. (2010). Causal thinking and complex system approaches in epidemiology. International Journal of Epidemiology, 39, 97-106. doi: DOI 10.1093/ije/dyp296.

Gilioli, G., Schrader, G., \& Baker, R.H.A. (2014). Environmental risk assessment for plant pests: A procedure to evaluate their impacts on ecosystem services. Science of The Total Environment, 468-469, 475-486. doi: 10.1016/j. scitotenv.2013.08.068

Githeko, A.K., Ogallo, L., Lemnge, M., Okia, M., 2014. Development and validation of climate and ecosystem-based early malaria epidemic prediction models in East Africa. Malar. J. 13 (329).

Gómez-Baggethun, E., Barton, D.N., 2013. Classifying and valuing ecosystem services for urban planning. Ecol. Econ. 86, 235-245. http://dx.doi.org/10.1016/j. ecolecon.2012.08.019.

Gruebner, O., Lowe, S.R., Sampson, L., \& Galea, S. (2015). The geography of postdisaster mental health: spatial patterning of psychological vulnerability and resilience factors in New York City after Hurricane Sandy. International Journal of Health Geographics, 14, 16. doi: 10.1186/s12942-015-0008-6.

Haines-Young, R., Potschin, M., 2010. The links between biodiversity, ecosystem services and human well-being. In: Raffaelli, D.G., Frid, C.L.J. (Eds.), Ecosystem Ecology. Cambridge University Press, A New Synthesis.

Hajat, S., Ebi, K.L., Kovats, R.S., Menne, B., Edwards, S., Haines, A., 2005. The Human Health Consequences of Flooding in Europe: a Review. In: Kirch, W., Bertollini, R., Menne, B. (Eds.), Extreme Weather Events and Public Health Responses. Springer Berlin Heidelberg, pp. 185-196.

Hansen, A., Bi, P., Nitschke, M., Ryan, P., Pisaniello, D., Tucker, G., 2008. The effect of heat waves on mental health in a temperate Australian city. Environ. Health Perspect. 116 (10), 1369-1375. http://dx.doi.org/10.1289/ehp.11339.
Hanski, I., von Hertzen, L., Fyhrquist, N., Koskinen, K., Torppa, K., Laatikainen, T., Haahtela, T., 2012. Environmental biodiversity, human microbiota, and allergy are interrelated. Proc. Natl. Acad. Sci. 109 (21), 8334-8339. http://dx.doi.org 10.1073/pnas.1205624109.

Hartig, T., Mitchell, R., De Vries, S., Frumkin, H., 2014. Nature and Health. Annu. Rev. Public Health 35, 207-228. http://dx.doi.org/10.1146/ annurev-publhealth-032013-182443.

Henke, J.M., \& Petropoulos, G.P. (2013). A GIS-based exploration of the relationships between human health, social deprivation and ecosystem services: The case of Wales, UK. Applied Geography, 45(0), 77-88. doi: 10.1016/j.apgeog.2013.07.022.

Hinga, K.R., Batchelor, A., 2005. Waste Processing and Detoxification. In: Hassan, R. Scholes, R., Ash, N. (Eds.), Ecosystems and Human Well-being Volume 1. Current State and Trends, Washington DC.

Honold, J., Lakes, T., Beyer, R., \& van der Meer, E. (2015). Restoration in Urban Spaces: Nature Views From Home, Greenways, and Public Parks. Environment and Behavior. doi: 10.1177/0013916514568556.

Huber, M., Knottnerus, J.A., Green, L., Horst, H., v.d., Jadad, A.R., Kromhout, D., Smid, H., 2011. How should we define health. BMJ 343. http://dx.doi.org/10.1136/bmj. d4163.

Huynen, M.M.T.E., Martens, P., Hilderink, H.B.M., 2005. The Health Impacts of Globalisation: a Conceptual Framework. . Glob. Health 1 (14).

Ivers, L.C., \& Ryan, E.T. (2006). Infectious diseases of severe weather-related and flood-related natural disasters. Current Opinion in Infectious Diseases, 19(5), 408-414. doi: 10.1097/01.qco.0000244044.85393.9e.

Jackson, L.E., Daniel, J., McCorkle, B., Sears, A., \& Bush, K.F. (2013). Linking ecosystem services and human health: the Eco-Health Relationship Browser. International Journal of Public Health, 58, 747-755. http://dx.doi.org/10.1146/annurev.en viron.033108.102650.

Jadhav, S., Barua, M., 2012. The Elephant Vanishes: Impact of human-elephant conflict on people's wellbeing. . Health Place 18 (6), 1356-1365. http://dx.doi. org/10.1016/j.healthplace.2012.06.019.

Jarup, L., Hellstrom, L., Alfven, T., Carlsson, M., Grubb, A., Persson, B., Elinder, C., 2000. Low level exposure to cadmium and early kidney damage: the OSCAR study. Occup. Environ. Med. 57 (10), 668-672. http://dx.doi.org/10.1136/ oem.57.10.668.

Jin, A., Lalonde, C.E., Brussoni, M., McCormick, R., George, M.A., 2015. Injury Hospitalizations Due to Unintentional Falls among the Aboriginal Population of British Columbia, Canada: Incidence, Changes over Time, and Ecological Analysis of Risk Markers, 1991-2010. Vol. 10(3), p. e0121694. doi: 10.1371/journal. pone.0121694.

Jones, A.E., Morse, A.P., 2009. Application and validation of a seasonal ensemble prediction system using a dynamic malaria model. J. Clim. 23, 4202-4215.

Kardan, O., Gozdyra, P., Misic, B., Moola, F., Palmer, L.J., Paus, T., Berman, M.G., 2015 Neighborhood greenspace and health in a large urban center. Sci. Rep. 5, 11610. http://dx.doi.org/10.1038/srep11610.

Keesing, F., Belden, L.K., Daszak, P., 2010. Impacts of biodiversity on the emergence and transmission of infectious diseases. Nature 468, 647-652. http://dx.doi.org/ 10.1038/nature09575.

Keesing, F., Ostfeld, R.S., 2015. Is biodiversity good for your health? Science 349 (6245), 235-236. http://dx.doi.org/10.1126/science.aac7892.

Kettunen, M., Bassi, S., Gantioler, S., Ten Brink, P., 2009. Assessing socio-economic benefits of natura 2000-A toolkit for practitioners. Institute for European Environmental Policy (IEEP), Brussels.

Keune, H., Cretsch, C., De Blust, G., 2013a. Science-policy challenges for biodiversity, public health and urbanization: examples from Belgium. Environ. Res. Lett. 8 (025015), 19. http://dx.doi.org/10.1088/1748-9326/8/2/025015.

Keune, H., Martens, P., Kretsch, C., Prieur-Richard, A., 2013b. Chapter 16-The Natura Relation between Biodiversity and Public Health: An Ecosystem Services Perspective. In: Jacobs, S., Dendoncker, N., Keune, H. (Eds.), Ecosystem Services. Elsevier, Boston, pp. 181-189.

Khan, S., Ahmad, I., Shah, M.T., Rehman, S., Khaliq, A., 2009. Use of constructed wetland for the removal of heavy metals from industrial wastewater. J. Environ. Manag. 90 (11), 3451-3457. http://dx.doi.org/10.1016/j.jenvman.2009.05.026.

Lafferty, K.D., Wood, C.L., 2013. It's a myth that protection against disease is a strong and general service of biodiversity conservation: Response to Ostfeld and Keesing. Trends Ecol. Evol. 28 (9).

Laporta, G.Z., Prado, P.I.K.Ld, Kraenkel, R.A., Coutinho, R.M., Sallum, M.A.M., 2013. Biodiversity Can Help Prevent Malaria Outbreaks in Tropical Forests. Plos. Negl. Trop. Dis. 7 (3), e2139. http://dx.doi.org/10.1371/journal.pntd.0002139.

Levy, K., Daily, G., Myers, S.S., 2012. Human Health as an Ecosystem Service: A Conceptual Framework. In: Ingram, J.C., DeClerck, F., Rumbaitis del Rio, C. (Eds.) Integrating Ecology and Poverty Reduction. Island Press, Washington, pp. 231-251.

Levy M., Babu, S., \& Hamilton, K. (2005). Ecosystem Conditions and Human Wellbeing. in: Hassan, R., Scholes, R. \& Ash, N. (Eds.), Ecosystems and Human Wellbeing: Current State and Trends, Volume 1. Washington DC.

Liddell, C., \& Morris, C. (2010). Fuel poverty and human health: A review of recen evidence. Energy Policy, 38(6), 2987-2997. doi: 10.1016/j.enpol.2010.01.037.

Liekens, I., Broekx, S., Smeets, N., Staes, J., Van der Biest, K., Schaafsma, M., Cerulus, T., 2013. Chapter 19-The Ecosystem Services Valuation Tool and its Future Developments. In: Jacobs, S., Dendoncker, N., Keune, H. (Eds.), Ecosystem Services. Elsevier, Boston, pp. 249-262.

Lottrup, L., Grahn, P., \& Stigsdotter, U.K. (2013). Workplace greenery and perceived level of stress: Benefits of access to a green outdoor environment at the workplace. Landscape and Urban Planning, 110(0), 5-11. doi: 10.1016/j. landurbplan.2012.09.002. 
Lovasi, G.S., O’Neil-Dunne, J.P.M., Lu, J.W.T., 2013. Urban tree canopy and asthma, wheeze, rhinitis, and allergic sensitization to tree pollen in a New York City Birth Cohort. Environ. Health Perspect. 121 (4), 494-500. http://dx.doi.org/ 10.1289/ehp.1205513.

Lyytimäki, J. (2014). Bad nature: Newspaper representations of ecosystem disservices. Urban Forestry \& Urban Greening, 13(3), 418-424. doi: 10.1016/j. ufug.2014.04.005

Lyytimäki, J. (2015). Ecosystem disservices: Embrace the catchword. Ecosystem Services, 12, 136. doi: 10.1016/j.ecoser.2014.11.008.

Lyytimäki, J., Petersen, L.K., Normander, B., \& Bezák, P. (2008). Nature as a nuisance? Ecosystem services and disservices to urban lifestyle. Environmental Sciences, 5 (3), 161-172. doi: 10.1080/15693430802055524.

Lyytimäki, J., \& Sipila, M. (2009). Hopping on one leg - The challenge of ecosystem disservices for urban green management. Urban Forestry \& Urban Greening, 8 309-315.

MA. (2003). Ecosystems and Human Well-being, a Framework for Assessment. Washington DC.

MA, 2005a.

MA, 2005b. Ecosystems and Human Well-Being: Desertification Synthesis. WHO, Geneva, pp. 4-8.

MA, 2005c. Ecosystems and Human Well-Being: Health Synthesis. Geneva: WHO. MA, 2005d. Ecosystems and Human Well-being: Synthesis. Washington DC.

Mace, G., Masundire, H., Baillie, J., 2005. Biodiversity. In: Hassan, R., Scholes, R., Ash, N. (Eds.), Ecosystems and Human Well-being Volume 1. Current State and Trends, Washington DC.

Maes, J., Egoh, B., Willemen, L., Liquete, C., Vihervaara, P., Schägner, J.P., . Bidoglio, G., 2012. Mapping ecosystem services for policy support and decision making in the European Union. Ecosyst. Serv. 1 (1), 31-39. http://dx.doi.org/10.1016/j. ecoser.2012.06.004

Maes, J., Teller, A., Erhard, M., 2013. Mapping and Assessment of Ecosystems and their Services. An Analytical Framework for Ecosystem Assessments Under Action 5 of the EU Biodiversity Strategy to 2020: European Union.

Martens, P., Huynen, M.M.T.E., 2003. A future without health? Health dimension in global scenario studies. Bull. World Health Organ. 81, 896-901.

Martens, P., Kovats, R.S., Nijhof, S., 1999. Climate change and future populations at risk from malaria. Glob. Environ. Chang. 9, 89-107.

Martínez-Harms, M.J., Balvanera, P., 2012. Methods for mapping ecosystem service supply: a review. Int. J. Biodivers. Sci. Ecosyst. Serv. Manag. 8 (1-2), 17-25. http: //dx.doi.org/10.1080/21513732.2012.663792.

Mathers, C., Stevens, G., 2013. WHO methods and data sources for global burden of disease estimates 2000-2011. WHO, Geneva.

McIvor, A., Spencer, T., Möller, I., Spalding, M., 2012. Storm Surge Reduction by Mangroves Natural Coastal Protection Series: Report 2 (Vol. Cambridge Coastal Research Unit Working Paper 41). The Nature Conservancy and Wetlands International, Geneva.

McLaren, L., Hawe, P., 2005. Ecological perspectives in health research. J. Epidemiol. Community Health 59, 6-14.

McMichael, A.J., 1999. Prisoners of the proximate: loosening the constraints on epidemiology in an age of change. Am. J. Epidemiol. 10, 887-897.

Mendez, D. (2010). A systems approach to a complex problem. American Journal of Public Health, 100(7), 1160.

Mendonça de Carvalho, R., 2013. Ecosystem Services and Urban Vegetation Coverage in Belèm: the influence on noise pollution, air pollution and climate regulation,... Universidade Federal do Pará

Miller, K.A., Siscovick, D.S., Sheppard, L., Shepherd, K., Sullivan, J.H., Anderson, G. L., Kaufman, J.D. (2007). Long-Term Exposure to Air Pollution and Incidence of Cardiovascular Events in Women. New England Journal of Medicine, 356(5) 447-458, doi: doi:10.1056/NEJMoa054409.

Ming, J., Xian-guo, L., Lin-shu, X., Li-juan, C., Shouzheng, T. (2007). Flood mitigation benefit of wetland soil - A case study in Momoge National Nature Reserve in China. Ecological Economics, 61(2-3), 217-223. doi: 10.1016/j. ecolecon.2006.10.019.

Mischler, P., Kearney, M., McCarroll, J.C., 2012. Environmental and socio-economic risk modelling for Chagas disease in Bolivia. Geospatial Health 6 (3), 59-66.

Morris, G., 2010. Ecological public health and climate change policy. Perspect. Public Health 130, 34-40.

Münzel, T., Gori, T., Babisch, W., Basner, M., 2014. Cardiovascular effects of environmental noise exposure. Eur. Heart J. 35 (13), 829-836. http://dx.doi.org 10.1093/eurheartj/ehu030.

Myers, S.S., Gaffikin, L., Golden, C.D., Ostfeld, R.S., Redford, K.H., Ricketts, T.H., Osofsk, S.A., 2013. Human health impacts of ecosystem alteration. Proc. Natl. Acad. Sci. 110 (47), 18753-18760.

Myers, S.S., Patz, J., 2009. Emerging threats to human health from global environmental change. Annu. Rev. Environ. Resour. 34, 223. http://dx.doi.org/10.1146 annurev.environ.033108.102650.

Mace, G., Masundire, H., \& Baillie, J. (2005). Biodiversity Ecosystems and Human Well-being: Current State and Trends, Volume 1. Washington DC.

Maas, J., Verheij, R.A., de Vries, S., Spreeuwenberg, P., Schellevis, F.G., \& Groenewegen, P.P. (2009). Morbidity is related to a green living environment. Journa of Epidemiology and Community Health, 63(12), 967-973. doi: 10.1136 jech.2008.079038.

Nielsen, T.S., \& Hansen, K.B. (2007). Do green areas affect health? Results from a Danish survey on the use of green areas and health indicators. Health \& Place, 13(4), 839-850. doi: 10.1016/j.healthplace.2007.02.001.

Nmor, J.C., Sunahara, T., \& Goto, K. (2013). Topographic models for predicting malaria vector breeding habitats: potential tools for vector control managers.
Parasites \& Vectors, 6(14)

Natural Economy Northwest, CABE, Natural England, Yorkshire Forward, The Northern Way, Design for London, ... LLP, Genecon. (2014). Building natural value for sustainable economic development-The green infrastructure valuation toolkit user guide (Vol. V1.3).

Nowak, D.J., Hirabayashi, Satoshi, Bodine, Allison, Greenfield, Eric, 2014. Environ. Pollut. 193, 119-129. http://dx.doi.org/10.1016/j.envpol.2014.05.028.

O'Farrell, P.J., Donaldson, J.S., Hoffmana, M.T., 2007. The influence of ecosystem goods and services on livestock management practices on the Bokkeveld plateau, South Africa. Agric. Ecosyst. Environ. 122 (3), 312-324. http://dx.doi.org/ 10.1016/j.agee.2007.01.025.

Pataki, D.E., Carreiro, M.M., Cherrier, J., Grulke, N.E., Jennings, V., Pincetl, S., Zipperer, W.C., 2011. Coupling biogeochemical cycles in urban environments: ecosystem services, green solutions, and misconceptions. Front. Ecol. Environ. 9 (1), 27-36. http://dx.doi.org/10.1890/090220.

Patil, A.P., Gething, P.W., Piel, F.B., 2011. Bayesian geostatistics in health cartography: the perspective of malaria. Trends Parasitol. 27 (6), 246-253.

Patz, J.A., \& Confalonieri, U.E.C. (2005). Human Health: Ecosystem Regulation of Infectious Diseases. in: Hassan, R., Scholes, R. \& Ash, N. (Eds.), Ecosystems and Human Well-being: Current State and Trends, Volume 1. Washington DC.

Pereira, G., Christian, H., Foster, S., 2013. The association between neighborhood greenness and weight status: an observational study in Perth Western Australia. Environ. Health, 12

Pongsiri, M.J., Roman, J., Ezenwa, V.O., Goldberg, T.L., Koren, H.S., Newbold, S.C., Salkeld, D.J., 2009. Biodiversity Loss Affects Global Disease Ecology. BioScience 59 (11), 945-954. http://dx.doi.org/10.1525/bio.2009.59.11.6.

Pope 3rd, C.A., Burnett, R.T., Thun, M.J., Calle, E.E., Krewski, D., Ito, K., Thurston, G.D. 2002. Lung cancer, cardiopulmonary mortality, and long-term exposure to fine particulate air pollution. JAMA 287 (9), 1132-1141.

Powe, N.A., Willis, K.G., 2004. Mortality and morbidity benefits of air pollution (SO2 and PM10) absorption attributable to woodland in Britain. J. Environ. Manag. 70 (2), 119-128. http://dx.doi.org/10.1016/j.jenvman.2003.11.003.

Prescott, G.J., Cohen, G.R., Elton, R.A., Fowkes, F.G., Agius, R.M., 1998. Urban air pollution and cardiopulmonary ill health: a 14.5 year time series study. Occup. Environ. Med. 55 (10), 697-704.

Project, M.A.. (2015). Malaria Atlas Project. Retrieved August, 2015, from 〈http:// www.map.ox.ac.uk/

Pickard, B.R., Daniel, Jessica, Mehaffey, Megan, Jackson, Laura E., Neale, Anne, 2015. EnviroAtlas: A new geospatial tool to foster ecosystem services science and resource management. Ecosyst. Serv. 14, 45-55. http://dx.doi.org/10.1016/j. ecoser.2015.04.005.

Randolph, S.E., Dobson, A.D.M., 2012. Pangloss revisited: a critique of the dilution effect and the biodiversity-buffers-disease paradigm. Parasitology 139 (7), 847-863. http://dx.doi.org/10.1017/S0031182012000200.

Rayner, G., Lang, T., 2012. Ecological Public Health. Earthscan, New York.

Reacher, M., McKenzie, K., Lane, C., Nichols, T., Kedge, I., Iversen, A., Simpson, J., 2004. Health impacts of flooding in Lewes: a comparison of reported gastrointestinal and other illness and mental health in flooded and non-flooded households. Commun. Dis. Public Health/PHLS 7 (1), 39-46.

Reis, S., Morris, G., Fleming, L.E., Beck, S., Taylor, T., White, M., Austen, M., 2015. Integrating health and environmental impact analysis. Public Health 129 (10), 1383-1389. http://dx.doi.org/10.1016/j.puhe.2013.07.006.

Rook, G.A., 2013. Regulation of the immune system by biodiversity from the natural environment: An ecosystem service essential to health. Proc. Natl. Acad. Sci. 110 (46), 18360-18367. http://dx.doi.org/10.1073/pnas.1313731110.

Rook, G.A.W., Raison, C.L., Lowry, C.A., 2014. Microbial 'old friends', immunoregulation and socioeconomic status. Clin. Exp. Immunol. 177 (1), 1-12. http://dx.doi.org/10.1111/cei.12269.

Roy, S., Byrne, J., Pickering, C., 2012. A systematic quantitative review of urban tree benefits, costs, and assessment methods across cities in different climatic zones. Urban For. Urban Green. 11 (4), 351-363. http://dx.doi.org/10.1016/j. ufug.2012.06.006.

Ruokolainen, L., von Hertzen, L., Fyhrquist, N., Laatikainen, T., Lehtomäki, J., Auvinen, P., Hanski, I., 2015. Green areas around homes reduce atopic sensitization in children. Allergy 70 (2), 195-202. http://dx.doi.org/10.1111/all.12545.

Sahani, M., Zainon, N.A., Wan Mahiyuddin, W.R., Latif, M.T., Hod, R., Khan, M.F., Chan, C.-C., 2014. A case-crossover analysis of forest fire haze events and mortality in Malaysia. Atmos. Environ. 96, 257-265. http://dx.doi.org/10.1016/j. atmosenv.2014.07.043.

Sandifer, P.A., Sutton-Grier, A.E., Ward, B.P., 2015. Exploring connections among nature, biodiversity, ecosystem services, and human health and well-being: Opportunities to enhance health and biodiversity conservation. Ecosyst. Serv. 12 (0), 1-15. http://dx.doi.org/10.1016/j.ecoser.2014.12.007.

Sari Kovats, R., Hajat, S., 2008. Heat stress and public health: a critical review. Annu. Rev. Public Health 29, 41-55. http://dx.doi.org/10.1146/annurev. publhealth.29.020907.090843.

Schoonover, J., Williard, K.J., Zaczek, J., Mangun, J., \& Carver, A. (2005). Nutrient Attenuation in Agricultural Surface Runoff by Riparian Buffer Zones in Southern Illinois, USA. Agroforest Syst, 64(2), 169-180. doi: 10.1007/s10457-004-0294-7.

Shapiro, J., \& Báldi, A. (2014). Accurate accounting: How to balance ecosystem services and disservices. Ecosystem Services, 7(0), 201-202. doi: 10.1016/j. ecoser.2014.01.002.

Sinka, M.E., Bangs, M.J., \& Manguin, S. (2011). The dominant Anopheles vectors of human malaria in the Asia-Pacific region: occurrence data, distribution maps and bionomic précis. Parasites \& Vectors, 4(89).

Song, C., Ikei, H., Igarashi, M., Miwa, M., Takagaki, M., \& Miyazaki, Y. (2014). 
Physiological and psychological responses of young males during spring-time walks in urban parks. Journal of Physiological Anthropology, 33(1), 8.

Soskolne, C., \& Broemling, N. (2002). Eco-epidemiology: on the need to measure health effects from global change. Global Change \& Human Health, 3(1), 58-66. Soskolne, C., Butler, C., IJsselmuiden, C., London, L., \& von Schirnding, Y. (2007). Toward a global agenda for research in environmental epidemiology. Epidemiology and Society, 18(1), 162-166.

States, S.L., Brinkerhoff, R.J., Carpi, G., Steeves, T.K., Folsom-O’Keefe, C., DeVeaux, M., Diuk-Wasser, M.A., 2014. Lyme disease risk not amplified in a species-poor vertebrate community: Similar Borrelia burgdorferi tick infection prevalence and OspC genotype frequencies. Infect. Genet. Evol. 27, 566-575. http://dx.doi. org/10.1016/j.meegid.2014.04.014.

Sterman, J. (2006). Learning form evidence in a complex world. American Journal of Public Health, 96(3), 505-514.

Stresman, G.H. (2010). Beyond temperature and precipitation: Ecological risk factors that modify malaria transmission. Acta Tropica, 116(3), 167-172. doi: 10.1016/j.actatropica.2010.08.005

Stryker, J.J., \& Bomblies, A. (2012). The impacts of land use change on malaria vector abundance in a water-limited, highland region of Ethiopia. Ecohealth, 9(4), 455470. doi: 10.1007/s10393-012-0801-7.

Sugiyama, T., Leslie, E., Giles-Corti, B., Owen, N., 2008. Associations of neighbourhood greenness with physical and mental health: do walking, social coherence and local social interaction explain the relationships? J. Epidemiol. Commun. Health 62 (5), e9. http://dx.doi.org/10.1136/jech.2007.064287.

Susser, M., \& Susser, E. (1996). Choosing a future for epidemiology: II. From black box to Chinese boxes and eco-epidemiology. Am J Public Health, 86, 674-677.

Sharp, R., Tallis, H.T., Ricketts, T., Guerry, A.D., Wood, S.A., Chaplin-Kramer, R., Bierbower, W., 2015. InVEST User's Guide: The Natural Capital Project. Stanford University, University of Minnesota, The Nature Conservancy, and World Wildlife Fund.

Tagaris, E., Liao, K.-J., DeLucia, A.J., Deck, L., Amar, P., Russell, A.G., 2009. Potential impact of climate change on air pollution-related human health effects. Environ. Sci. Technol. 43 (13), 4979-4988. http://dx.doi.org/10.1021/es803650w.

Timm, S., Svanes, C., Janson, C., Sigsgaard, T., Johannessen, A., Gislason, T., Schlunssen, V., 2014. Place of upbringing in early childhood as related to inflammatory bowel diseases in adulthood: a population-based cohort study in Northern Europe. Eur. J. Epidemiol. 29 (6), 429-437. http://dx.doi.org/10.1007/ s10654-014-9922-3.

The Nature Conservancy. (2015). Coastal Resilience mapping portal. Retrieved August, 2015, from maps.coastalresilience.org/network.

Tomalak, M., Rossi, E., Ferrini, F., \& Moro, P.A. (2011). Negative Aspects and Hazardous Effects of Forest Environment on Human Health. in: Nilsson, K., Sangster, M., Gallis, C., Hartig, T., De Vries, S., Seeland, K. \& Schipperijn, J.'(Eds.), Forests, Trees and Human Health (pp. 77-124): Springer Netherlands.

Trochim, W., Cabrera, D., Milstein, B., Gallagher, R., \& Leischow, S. (2006). Practical challenges of systems thinking and modeling in public health. American Journal of Public Health, 96(3), 538- 546.

Turkelboom, F., Raquez, P., Dufrêne, M., Raes, L., Simoens, I., Jacobs, S., Keune, H. 2013. Chapter 18-CICES Going Local: Ecosystem Services Classification Adapted for a Highly Populated Country. In: Jacobs, S., Dendoncker, N., Keune, H. (Eds.), Ecosystem Services. Elsevier, Boston, pp. 223-247.

UK-NEA. (2015). Ecosystem Services. 2015, from uknea.unep-wcmc.org.

UNDPA. (2015). i-Tree Eco. Retrieved August, 2015, from 〈http://www.itreetools.org/ eco/ $/$.

UNEP. (2008a). Water Quality for Ecosystem and Human Health (2 ed.): Fauna and Flora International.

Valkanova, V., Ebmeier, K.P., Allan, C.L., 2013. CRP, IL-6 and depression: a systematic review and meta-analysis of longitudinal studies. J. Affect. Disord. 150 (3), 736-744. http://dx.doi.org/10.1016/j.jad.2013.06.004.

Valle, D., Clark, J., 2013. Conservation efforts may increase malaria burden in the brazilian amazon. PLoS ONE 8 (3), e57519. http://dx.doi.org/10.1371/journal. pone.0057519.

Van Dijk, R., Jansen, L., Merkx, L., \& Van Wetten, J. (2013). Van TEEB-stad naar TEEBstad tool, Inzicht in de waarde van groen in de stad: Platform31.

Van Lieshout, M., Kovatsb, R.S., Livermore, M.T.J., 2004. Climate change and malaria: analysis of the SRES climate and socio-economic scenarios. Clim. Chang. 14 (1), 87-99.

Villa, F., Bagstad, K.J., Voigt, B., 2014a. A methodology for adaptable and robust ecosystem services assessment. PLoS ONE 9, e91001.

Villa, F., Bagstad, K.J., Voigt, B., Johnson, G.W., Athanasiadis, I.N., Balbi, S., 2014b. The misconception of ecosystem disservices: how a catchy term may yield the wrong messages for science and society. Ecosyst. Serv. 10 (0), 52-53. http://dx. doi.org/10.1016/j.ecoser.2014.09.003.

Villanueva, C., Durand, G., Coutte, M., Chevrier, C., \& Cordier, S. (2005). Atrazine in municipal drinking water and risk of low birth weight, preterm delivery, and small-for-gestational-age status. Occupational and Environmental Medicine, 62 (6), 400-405. doi: 10.1136/oem.2004.016469.

Von Döhren, P., Haase, D., 2015. Ecosystem disservices research: a review of the state of the art with a focus on cities. Ecol. Indic. 52 (0), 490-497. http://dx.doi. org/10.1016/j.ecolind.2014.12.027.

Wade, T.J., Sandhu, S.K., Levy, D., Lee, S., LeChevallier, M.W., Katz, L., Colford, J.M., 2004. Did a severe flood in the midwest cause an increase in the incidence of gastrointestinal symptoms? Am. J. Epidemiol. 159 (4), 398-405. http://dx.doi. org/10.1093/aje/kwh050.

Ward, M.H., Kilfoy, B.A., Weyer, P.J., Anderson, K.E., Folsom, A.R., \& Cerhan, J.R. (2010). Nitrate intake and the risk of thyroid cancer and thyroid disease. Epidemiology, 21(3), 389-395. doi: 10.1097/EDE.0b013e3181d6201d.

Webb, J.C., Mergler, D., Parkes, M.W., 2010. Tools for thoughtful action: the role of ecosystem approaches to health in enhancing public health. Can. J. Public Health 101 (6), 439-441.

WEHAB, 2002. A Framework for Action on Energy. World Summit on Sustainable Development, Johannesburg, South Africa.

Wheeler, B., Lovell, R., Higgins, S., White, M., Alcock, I., Osborne, N., Depledge, M., 2015. Beyond greenspace: an ecological study of population general health and indicators of natural environment type and quality. Int. J. Health Geogr. 14 (1), 17.

Whitmee, S., Haines, A., Beyrer, C., Boltz, F., Capon, A.G., de Souza Dias, B.F., Yach, D. 2015. Safeguarding human health in the Anthropocene epoch: report of The Rockefeller Foundation-Lancet Commission on planetary health. The Lancet http://dx.doi.org/10.1016/S0140-6736(15)60901-1.

WHO, 2006. Constitution of the World Health Organisation (Vol. Forty-fifth edition). World Health Organisation, New York.

WHO. (2007). Rabies and envenomings: a neglected public health issue. Geneva: World Health Organization.

WHO. 2014. 〈http://www.who.int/healthinfo/global_burden_disease〉.

WHO, \& CBD Secretariat. (2015). Connecting Global Priorities: Biodiversity and Human Health: a State of Knowledge Review: World Health Organization.

Wittmer, H., Berghöfer, A., Förster, J., Almack, K., 2012. The value of nature for loca development. In: Wittmer, H., Gundimeda, H. (Eds.), The Economics of Ecosystems and Biodiversity in Local and Regional Policy and Management Vol 2015. Routledge, pp. 7-32.

Wolch, J., Jerrett, M., Reynolds, K., McConnell, R., Chang, R., Dahmann, N., Berhane K., 2011. Childhood obesity and proximity to urban parks and recreational resources: a longitudinal cohort study. Health Place 17 (1), 207-214. http://dx. doi.org/10.1016/j.healthplace.2010.10.001.

Wood, C.L., Lafferty, K.D., 2013. Biodiversity and disease: a synthesis of ecological perspectives on Lyme disease transmission. Trends Ecol. Evol. 28 (4), 239-247. http://dx.doi.org/10.1016/j.tree.2012.10.011.

Wu, J., Ren, C., Delfino, R.J., Chung, J., Wilhelm, M., \& Ritz, B. (2009). Association between Local Traffic-Generated Air Pollution and Preeclampsia and Preterm Delivery in the South Coast Air Basin of California.

Zhang, W., Ricketts, T.H., Kremen, C., Carney, K., \& Swinton, S.M. (2007). Ecosystem services and dis-services to agriculture. Ecological Economics, 64(2), 253-260. doi: 10.1016/j.ecolecon.2007.02.024.

Von Hertzen, L., Hanski, I., Haahtela, T., 2011a. Natural immunity. Biodiversity loss and inflammatory diseases are two global megatrends that might be related. Vol. 12(11), pp. 1089-1093. doi: 10.1038/embor.2011.195.

Von Hertzen, L.C., Joensuu, H., Haahtela, T., 2011b. Microbial deprivation, inflammation and cancer. Cancer Metastas- Rev. 30 (2), 211-223. http://dx.doi. org/10.1007/s10555-011-9284-1. 